\title{
Pre-drill pore pressure prediction and safe well design on the top of Tulamura anticline, Tripura, India: a comparative study
}

\author{
Mohatsim Mahetaji $^{1}$. Jwngsar Brahma ${ }^{1} \cdot$ Anirbid Sircar $^{1}$
}

Received: 25 June 2019 / Accepted: 24 November 2019 / Published online: 9 December 2019

(c) The Author(s) 2019

\begin{abstract}
The Tulamura anticline falls in the state Tripura, Northeast India. The anticline is extended up to neighbour country Bangladesh. The region is characterized by huge anticlines, normal faults and abnormally pressured formations which causes a wide margin of uncertainties in wildcat well planning and design. These geological complexities of Tulamura anticline make the drilling engineers more challenging. Therefore, a proper well design is essential in such a region to prevent blowout. Drilling engineer requires to maintain wellbore pressure between the pore pressure and fracture pressure to reduce the possibility of a kick and a formation damage. Pore pressure plays an important role to design a safe and economical well in such a high pressure and temperature reservoir. For wildcat drilling, only seismic data are available in the study area. There are various methods to predict pore pressure from seismic velocity data. Modified Eaton's method is widely used for the pore pressure prediction from seismic data in terms of the velocity ratio. Modified Eaton's equations may cause an error by manual selection of compaction trend line which is used to find normal compaction velocity. The main objectives of this study are to develop a new method to predict pore pressure and safe well design on the top of Tulamura anticline in terms of pore pressure. The new method is validated by a well-known method, modified Eaton's method, and RFT pressure data from offset wells. An excellent match with pore pressures estimated from RFT pressure data and predicted by new model along with modified Eaton's method is observed in this research work. The efficiency and accuracy level of the hybrid model is more as compared to other methods as it does not require compaction velocity data; thus, an error caused by manual compaction trend can be eliminated. Pore pressure predicted by new method indicates result up to the $6000 \mathrm{~m}$, which is up to the basement rock. The predicted pore pressures by new method are used as an input to calculate the fracture pressure by Hubbert and Willis method, Mathews and Killy method and modified Eaton's method. Equivalent mud weight selection is carried out using median line principle with additional $0.3 \mathrm{ppg}, 0.3 \mathrm{ppg}$ and $0.2 \mathrm{ppg}$ of swab pressure, surge pressure and safety factor, respectively, for calculation of all casing pipes. Casing setting depths are selected based on pore pressure gradient, fracture pressure gradient and mud weight using graphical method. Here, four types of casing setting depths are selected: conductor, surface, intermediate and production casings at $100 \mathrm{ft}, 6050 \mathrm{ft}, 15500 \mathrm{ft}$ and 18,500 ft, respectively, by new methods, but the casing setting depths for intermediate are at $13500 \mathrm{ft}$ in the case of modified Eaton's method. The casing policy is selected based on burst pressure, collapse pressure and tension load. For each casing, kick tolerance in bbl is determined from kick tolerance graph to prevent the blowout. Finally, comparative safe and economical wells are designed on the top of Tulamura anticline along with target depth selection, casing setting depth selection, casing policy selection and kick tolerance in consideration of collapse pressure, burst pressure and tension load which gives a clear picture of well planning on the top of anticline in pore pressure point of view.
\end{abstract}

Keywords Pore pressure prediction $\cdot$ Seismic data $\cdot$ Tulamura Tripura $\cdot$ New method $\cdot$ Well design

\section{List of symbols}

$\mathrm{H}$

$\gamma$

Depth (ft)

Poisson's ratio

Jwngsar Brahma

jwngsar@gmail.com

Extended author information available on the last page of the article
$K_{i}$

$\mathrm{T}$

$\mathrm{PP}, P_{\mathrm{p}}$

$\mathrm{PF}, P_{\mathrm{f}}$

HP

$P_{\mathrm{ob}}$

$P_{\mathrm{pNormal}}$
Stress ratio

Two-way travel time ( $\mu \mathrm{s})$

Pore pressure (psi)

Fracture pressure (psi)

Hydrostatic pressure (psi)

Overburden pressure (psi)

Normal pore pressure (psi)

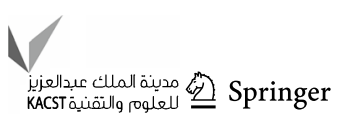




$\begin{array}{ll}\mathrm{GPP}, \frac{P_{\mathrm{p}}}{H} & \text { Pore pressure gradient (ppg) } \\ \mathrm{GPF}, \frac{P_{\mathrm{f}}}{H} & \text { Fracture pressure gradient (ppg) } \\ \mathrm{GOV}, \frac{P_{\mathrm{ov}}}{H} & \text { Overburden gradient (ppg) } \\ \frac{P_{\mathrm{v}}}{H} & \text { Effective stress gradient (ppg) } \\ \frac{P_{\mathrm{t}}}{H} & \text { Tectonic stress correction gradient } \\ & \text { (ppg) } \\ R_{\text {Normal }}, V_{\text {Normal }} & \begin{array}{l}\text { Normal resistivity and normal interval } \\ \text { velocity of the compacted core }\end{array} \\ R_{\text {observed }}, V_{\text {observed }} & \begin{array}{l}\text { Observed resistivity and observed } \\ \text { interval velocity of a core sample }\end{array}\end{array}$

\section{Introduction}

Pore pressure and fracture pressure are important parameters for drilling engineering to design a safe well in the wildcat area. Pore pressure and fracture pressure play a very significant role in well design and reservoir modelling. Pore pressures are determined by prediction method and detection method. The pressure is measured directly by taking a fluid sample from the formation in the direct method. Based on the complexity, performance and cost of method, drill stem testing (DST), wireline formation testing (RFT) and production testing (PT) are the order of test carried out with respect to time. The objectives of this study are to develop a new method to predict pore pressure and hence to design a safe well on the top of Tulamura anticline, Tripura, India, from seismic velocity data.

Pore pressure prediction equation from seismic data is given by the Karl (1996), Sayers et al. (2000), Matthews (1967), Eaton (1975), and Yan et al. (2013). Seismic interval velocities were estimated from the two-way seismic root mean square velocities (RMS velocity) by Dix's equation (Dix 1995). During seismic processing, seismic velocities are designed in such a way that the stack/migration is optimum with local fluctuation being smoothed and the velocity pic interval range is large for accurate pore pressure prediction.

Karl (1996) first estimated pore pressure from velocity using the simple experimental setup in 1948. This approach is working on effective stress, and it states that all measurable effects on the changes in stress are a function of effective vertical stress. This porosity-based approach is not working on the above abnormal pressure-causing mechanisms and leads to error formation pressure. Hottmann and Johnson (2007) estimated the formation of pressure by log-derived shale properties. This study was based on the logging data where the degree of compaction of shale is in response to compaction in axial stress. Pore pressure is related to the degree of compaction and burial depth. Hottmann and Johnson used shale acoustic and resistivity data to estimate reservoir formation pressure. Here, standard deviation on acoustic and resistivity method is 0.020 and $0.22 \mathrm{psi} / \mathrm{ft}$, respectively.

Matthews (1967) worked on pore and fracture pressure prediction and published an article in 1972. The purpose of that article was to show the relationship of lithologic properties indicated by $\operatorname{logs}$ that can be correlated to indicate pressure within the earth. Matthews and Kelly also presented a fracture pressure gradient equation. However, they introduced the concept of the variable horizontal-to-vertical stress ratio.

Eaton (1975) gave an equation for the prediction of overpressure from well logs. Eaton's equations are derived from the drilling parameter and well log. All four theoreticalbased equations give geo-pressure by the use of conductivity plot, resistivity plot, sonic travel time plot and D-exponent plot. The accuracy of geo-pressure by all equations is dependent on the quality of input data and method for the normal trend line.

Yan et al. (2013) gave the experiment-based equation for the pore pressure prediction from laboratory core measurement. In that study, pore pressure was predicted based on acoustic log and resistivity log data. Yan and Han's equation contained an effective stress coefficient which is estimated from laboratory measurement.

Brahma et al. (2013a, b) published an article on pre-drill pore pressure prediction using seismic velocity data on the flank and synclinal part of Atharamura anticline in the Eastern Tripura, India. They described the Atharamura anticline in eastern Tripura, which is the same in this study for validation and for further well planning. In that paper, they gave a proper flowchart to pore prediction from seismic velocity data and modified Eaton's equation was used to predict pore pressure and compare with RFT data.

In this work, modified Eaton's method and Yan method are studied thoroughly to predict pore pressure and derive an integrated approach for the pore pressure prediction. Pore pressure by the new method is validated by using RFT (repeat formation test) pressure data of the case study on the Tulamura anticline. Based on the new pore pressure from the integrated approach, the final well design is done on the top of the Tulamura anticline.

Fracture pressure was calculated by different methods based on an assumed Poisson ratio and stress anisotropy with depth and overburden pressure. Fracture pressure analysis is important for the well stimulation process. Hydrofracturing is necessary in order to increase production from conventional and non-conventional reservoir to increase mobility of fluid (Zhang et al. 2018; Dejam 2019a, b; Dejam and Hassanzadeh 2018; Dejam et al. 2018). Fracture pressure is calculated by Hubbert and Willis's equation (Hubbert and Rubey 1959), Matthews and Kelly's equation (Matthews 1967) and Eaton's equation 
(Eaton 1969). From overburden pressure and pore pressure are used to find out fracture pressure gradient. Constant Poisson's ratio (0.25) is used in Hubbert and Willis's equation to find out fracture pressure. Matthews and Kelly's equation was used for fracture pressure calculation by using a matrix stress coefficient (0.33). Eaton and modified Eaton's equations were used for fracture pressure calculation with variable Poisson's ratio which is from Poisson's ratio curve given by Eaton.

Brahma and Sircar (2018) further worked on the Atharamura anticline, Tripura, to design a safe well using seismic data on the top of Atharamura. The main objective of their work was planning a safe well over Atharamura anticline to explore and exploit hydrocarbons. Planning an exploratory well from seismic velocities aims to produce: pore pressure prediction, establishing drilling mud window, target depth selection, optimal mud policy, kick tolerance guidelines and the final well with casing policy.

Elmahdy et al. (2018) gave an idea about pore pressure prediction in unconventional carbonate reservoir by using porosity and compressibility attribute of the rocks. The objective of their work was to predict the formation pore pressure by using a modified Atashbari prediction model upon the wireline logging data. This model is applied to the carbonated reservoir of Middle Eocene Apollonia formation, Abu El Gharadig basin, Egypt. That model had been calibrated with direct pressure measurement (MDT) from the well for the best result.

Radwan et al. (2019) published an article on pore and fracture pressure modelling using direct and indirect methods in Badri Field, Gulf of Suez, Egypt. Objective of that work was to find out pore and fracture pressure prediction by direct and indirect method and to identify the overpressure zones in subsurface. All the pressure predictions were based on well logging data like resistivity, density, sonic and gamma-ray from offshore well in the Badri field. They used the Amoco overburden equation for calculation of overburden stress, while Eaton's equations are used for the pore pressure and fracture pressure prediction from sonic and resistivity logs.

A comparison of fracture pressure predicted by various methods is shown in results and discussions. Modified Eaton's method gave more realistic results for fracture pressure. Tectonic correction is very important for the geologically complex area to get an accreted fracture pressure. Modified Eaton's method considered tectonic correction so it gives the most accurate result for fracture pressure gradient. In this paper, we used modified Eaton's method for the further process of designing a safe well on the top of the Tulamura anticline. Finally, two exploratory wells are designed on the top of the Tulamura anticline based on the pre-drill pore pressure prediction and fracture pressure, drilling mud window, optimal mud policy selection, propose of safe casing policy with kick tolerance guidelines.

We proposed a new method for the pore pressure prediction based on seismic data. Previously, all the methods for the pore pressure prediction are dependent on the two-way travel time and normal compaction trend line velocity data. In this new method, pore pressure is not dependent on the normal compaction trend data so error caused by normal compaction trend data is eliminated and procedures of pore pressure prediction are the simple and actual representation of subsurface formation pressure.

In this work, the first part indicates the study area for a case study on the top of Tulamura anticline, Tripura, India. All geological and petrophysical properties are discussed and used for target depth selection and casing policy selection. After that, detailed methodology is described for proposed new method and methodology for the design of a well from pore pressure and fracture pressure is given in detail. After pore pressure prediction, new method is validated with RFT pressure data on the top of Tulamura anticline, Tripura, India. A comparison of two well design policies proposed by considering pore pressure by new method and modified Eaton's method is discussed in detail (Fig. 1). Finally, summary and conclusion give all the ideas about the new method, their advantages-disadvantages and proposed design of a safe well.

\section{Study area}

Tripura is a non-coastal state in Northeast India surrounded by six states: Assam, Mizoram, Arunachal Pradesh, Manipur, Nagaland and Meghalaya which are jointly known as the Seven Sister States. It spreads over $4050.86 \mathrm{~m}^{2}$ $\left(10,491.69 \mathrm{~km}^{2}\right)$. It ranges from $24^{\circ} 32^{\prime} \mathrm{N}$ to $22^{\circ} 56^{\prime} \mathrm{N}$, and $92^{\circ} 20^{\prime} \mathrm{E}$ to $91^{\circ} 09^{\prime} \mathrm{E}$. The physical geography of Tripura is categorized by plains, hill ranges and valleys. Tripura has five anticlinal ranges of peaks from north to south: Baramura in the west, through Atharamura, Longtharai and Shakhan, and Jampui Hills in the east. The intervening synclines are the Udaipur-Agartala, Teliamura-Khowai, Ambasa-Kamalpur, Kailasahar-Manu and Kanchanpur-Dharmanagar valleys (Development 2007).

The airborne gravity survey leads to the delineation of fourteen large closed anticlinal structures, viz., Langtarai, Gojalia, Skham, Baramura, Tichna, Atharamura, Tulamura, Machlithum, Batchia, Harargaj, Langai, Khubal, Rokhia, and Jampai anticlines, as shown in Fig. 2. A series of long and narrow anticlines with north-south-trending axial traces separated by board intervening synclines are present in Tripura fold belt thrust (FBT). In most of the anticlines, Middle Bhuban formation is capped by Upper Bhuban, Bokabil and Tipam formations (Fig. 3). High abnormal to superpressures

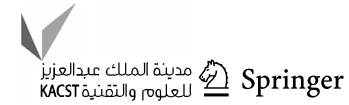




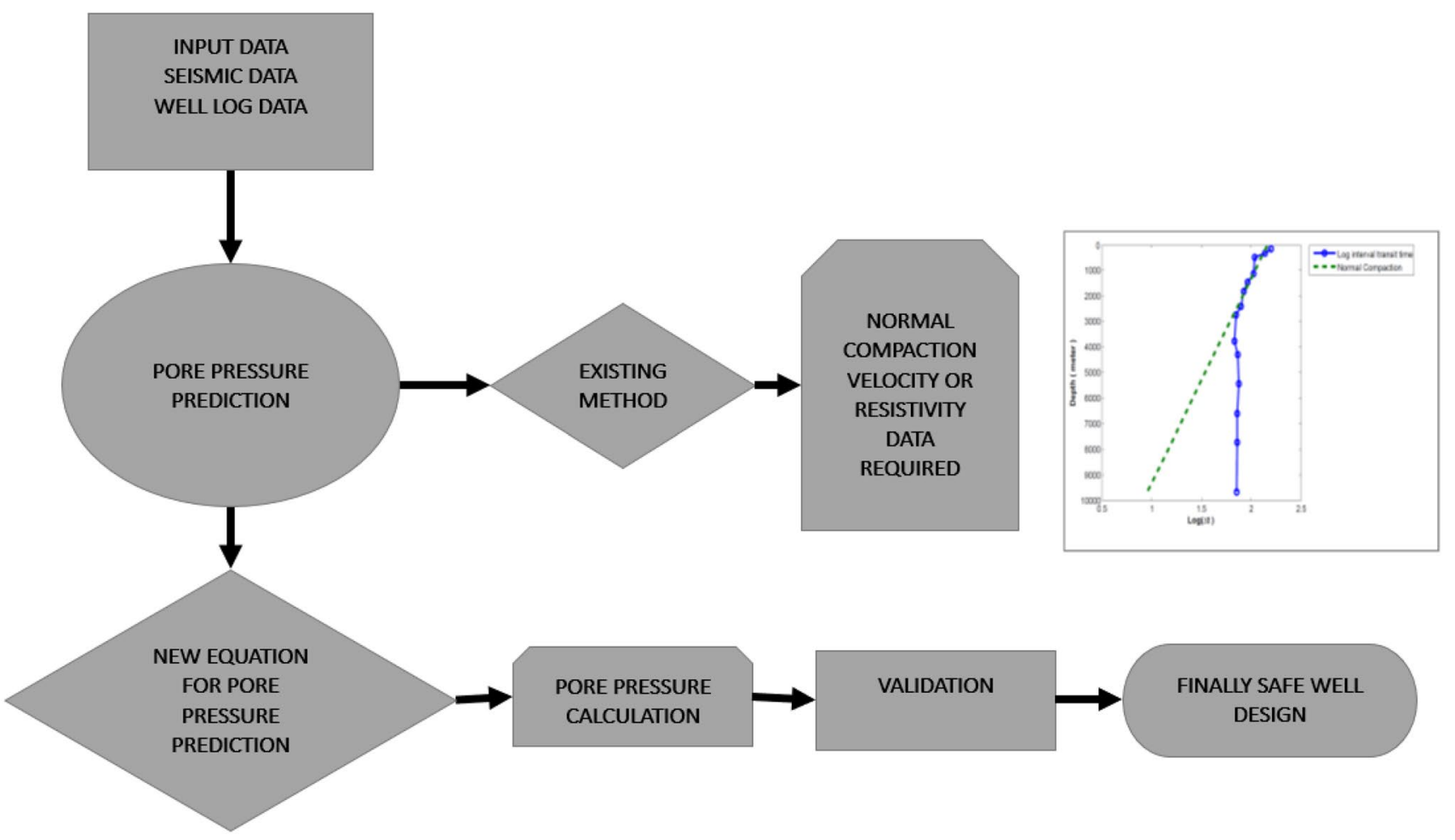

Fig. 1 Problem statement

are observed from Middle-Lower Bhuban, practically in all the structures of the Cachar area with pressure gradient reaching almost geostatic or even exceeding it. Compaction disequilibrium, aided partly by clay digenesis and tectonic activity, has been found responsible for the generation of overpressures in the Tripura area (Bhagwan et al. 1998).

The Tripura subbasin is constituted by a huge tertiary sedimentary sequence of post-Cretaceous to Pleistocene age (Momin and Choudhury 1999). The generalized stratigraphic section in the study area is indicated in Figs. 2, 3. All the wells drilled so far in Tripura have penetrated only up to Surma group of rocks. The Lower to Middle Miocene Surma group, consisting of the Bhuban formation and the overlying Bokabil formation, was deposited during repeated transgressions and regressions. These widespread units together reach more than $4500 \mathrm{~m}$ thickness in the Tripura fold belt and the deeper part of the Bengal basin. The sequence appears to thicken towards south and east and appears to have its depocenter in Mizoram (Chakravorty and Gupta 2011). Out of the three units within the Bhuban formation, the lowermost and the uppermost are mainly siltstones and fine-grained sandstone, alternating with mud rock, whereas the middle unit is composed of silty and sandy mudstone. The Bokabil formation generally consists of alternating mudstone, siltstone and fine- to medium-grained sandstones. The middle part of the Bokabil is more arenaceous and forms natural gas reservoirs in the Tripura as well as in the Bengal basin.

\section{Theory and methodologies}

The literature gives a clear idea about the pore pressure prediction by modified Eaton's method which is more promising than other pore pressure prediction methods. Pore pressure prediction by modified Eaton's method is dependent on input data and normal compaction velocity trend. For validation of pore pressure prediction, offset well pressure data are required. The pore pressure is predicted to develop a normal compaction curve with well depth and compare it with an actual compaction curve. Overpressure is calculated in terms of deviation from a normal trend. Normal compaction curve plays a critical role in determining the pore pressure prediction.

On the top of Tulamura anticline, two seismic sections at synclinal (A) and at flank (B) are taken. Both the seismic sections A and B are taken in a west-east direction. Normal (average) velocity and two-way travel time are taken as input data for various CDPs. Detail of prediction of pore pressure gradient and fracture pressure gradient process is described in Fig. 4.

\section{Pore pressure (PP)}

\section{Modified Eaton's method}

Modified Eaton's method predicts pore pressure by approximation of the effective vertical stress in terms of ratio 


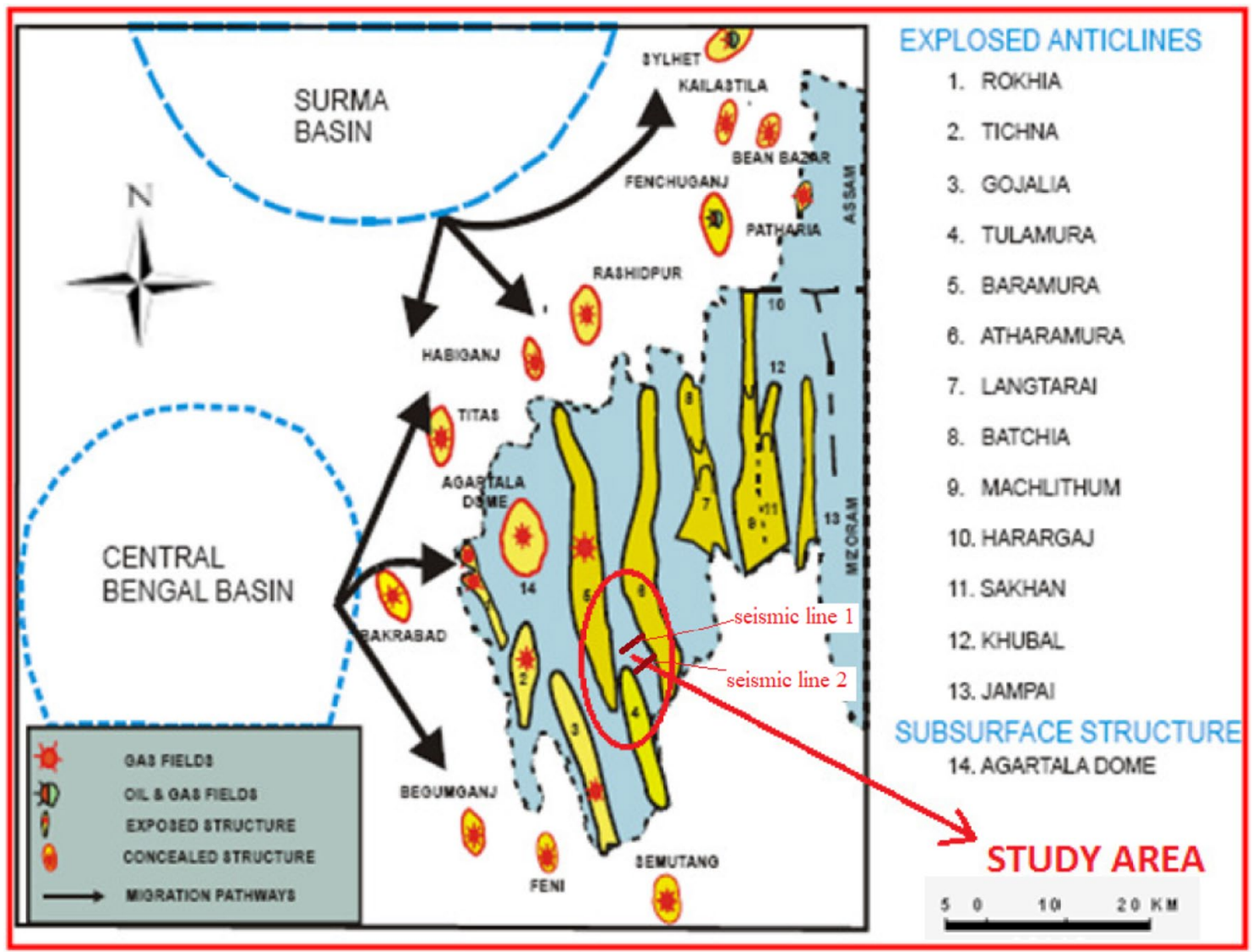

Fig. 2 Study area: Tulamura, Baramura and Atharamura anticlines (Jena et al. 2011)

resistivity and a ratio of sonic log velocities of observed value to normal value. For variable overburden gradient, the modified Eaton's equation is:

$P_{\mathrm{p}}=P_{\mathrm{ob}}-\left(P_{\mathrm{ob}}-P_{\mathrm{pNormal}}\right)\left(\frac{V_{\mathrm{observed}}}{V_{\text {Normal }}}\right)^{3}$

or

$P_{\mathrm{p}}=P_{\mathrm{ob}}-\left(P_{\mathrm{ob}}-P_{\mathrm{pNormal}}\right)\left(\frac{R_{\mathrm{observed}}}{R_{\text {Normal }}}\right)^{1.2}$

\section{Yan and Han's method}

Yan and Han worked on a new model for pore pressure prediction. Yan and Han's model for pore prediction was brought up based on the stress effect modelling of laboratory core measurement. Their model requires exactly the same inputs of modified Eaton's method and should have better performance in pore pressure prediction. Then performances of pore pressure prediction by using differential pressure and effective pressure, respectively, are compared.
$V_{\text {observed }}=V_{\text {Normal }}+3.87\left(e^{-1}-e^{-\frac{P_{o b}}{P_{\text {pNormal }}}}\right)$

The above two methods are pretty convenient to calculate the pore pressure only by using density and P-wave velocity data. However, $V_{\text {Normal }}$ is the necessary parameter for the two methods. When the acoustic logging curve is incomplete or fluctuates strongly, the calculated $V_{\text {Normal }}$ is not accurate enough, which will influence the accuracy of the results predicted by these two methods.

\section{Formulation of new method}

A new method is proposed in this study by the combination of Yan and modified Eaton's method. The specialty of our new model is that it eliminates the error caused by $V_{\text {Normal }}$. In our model, the normal velocity is not required which was very critical to determine. Due to the elimination of normal velocity in our model, the accuracy level is increased as compared to the existing models. New method can be represented as follows: 


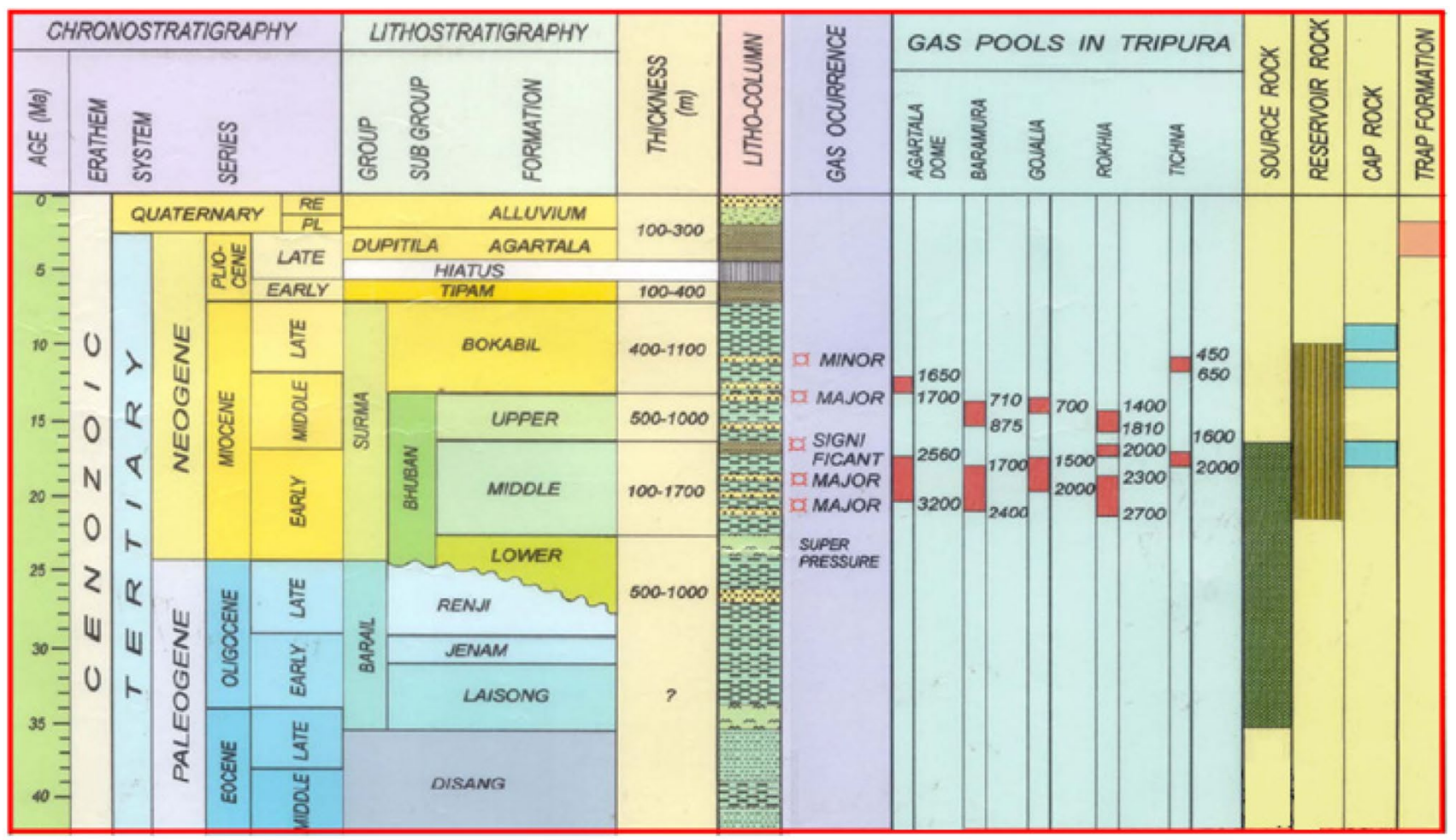

Fig. 3 Stratigraphy and petroleum system of Tripura, Assam-Arakan basin (Akram et al. 2004)

$\varepsilon=\mu-(\mu-1)\left(\frac{V_{\text {observed }}}{V_{\text {observed }}-3.87\left(\mathrm{e}^{-1}-\mathrm{e}^{-\varepsilon}\right)}\right)^{3}$

where $\varepsilon=P_{\mathrm{p}} / P_{\mathrm{pNormal}}$ and $\mu=P_{\mathrm{ob}} / P_{\mathrm{pNormal}}$.

\section{Fracture pressure (PF)}

Fracture pressure estimation is given by Hubbert-Willis's equation:

$\frac{P_{\mathrm{f}}}{H}=\frac{P_{\mathrm{t}}}{H}+\left(\frac{P_{\mathrm{ov}}}{H}-\frac{P_{\mathrm{p}}}{H}\right)\left(\frac{\gamma}{1-\gamma}\right)+\left(\frac{P_{\mathrm{p}}}{H}\right)$

For $\frac{P_{\mathrm{ov}}}{H}=1$ and $\gamma=0.25$, Eq. 5 reduces to:

$\frac{P_{\mathrm{f}}}{H}=\frac{1}{3}\left(\frac{P_{\mathrm{ov}}}{H}\right)+\frac{2}{3}\left(\frac{P_{\mathrm{p}}}{H}\right)$

Matthews and Kelly give similar Hubbert equation given by the ratio of variable horizontal stress to vertical stress given by Fig. 5 .

Matthews and Kelly's equation:
$\frac{P_{\mathrm{f}}}{H}=K_{i}\left(\frac{P_{\mathrm{v}}}{H}\right)+\left(\frac{P_{\mathrm{p}}}{H}\right)$

Eaton further improved Eq. (7) by familiarizing the variable overburden gradient and variable Poisson's ratio, where the ratio of lateral strain to longitudinal strain is given by Poisson's ratio. Eaton's relation for the fracture pressure is given by:

$\frac{P_{\mathrm{f}}}{H}=\frac{P_{\mathrm{t}}}{H}+\left(\frac{P_{\mathrm{ov}}}{H}-\frac{P_{\mathrm{p}}}{H}\right)\left(\frac{\gamma}{1-\gamma}\right)+\left(\frac{P_{\mathrm{p}}}{H}\right)$

Eaton's correlation of Poisson's ratio vs depth of the Gulf Coast is given in Fig. 6. From this relation, we calculate fracture pressure using Eaton's relation.

Fracture pressure by Eaton's relation has variable overburden pressure gradient and variable Poisson's ratio.

Fracture pressure by Eaton's correlation is needed tectonic stress correction so the final fracture pressure is exact.

Tectonic stress correction is given by:

$P_{\mathrm{t}}=\left(P_{\mathrm{ov}}-P_{\mathrm{p}}\right) *$ horizantal stress ratio

so that the final equation is known as the modified Eaton's equation for fracture pressure relation: 


\section{FLOW CHART}

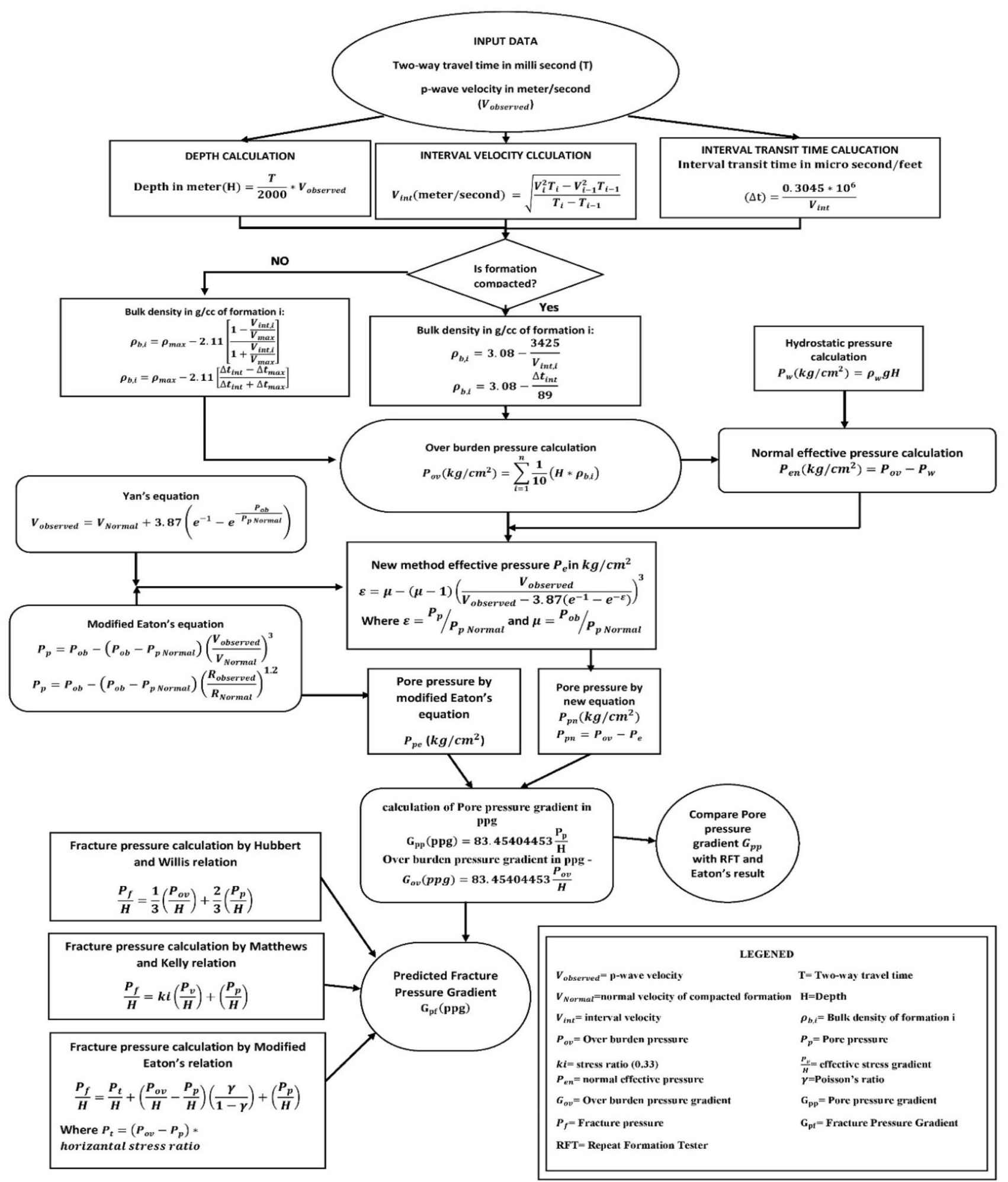

Fig. 4 Pore pressure prediction and fracture pressure prediction 
Fig. 5 Matrix stress coefficients of Matthews and Kelly (Matthews 1967)

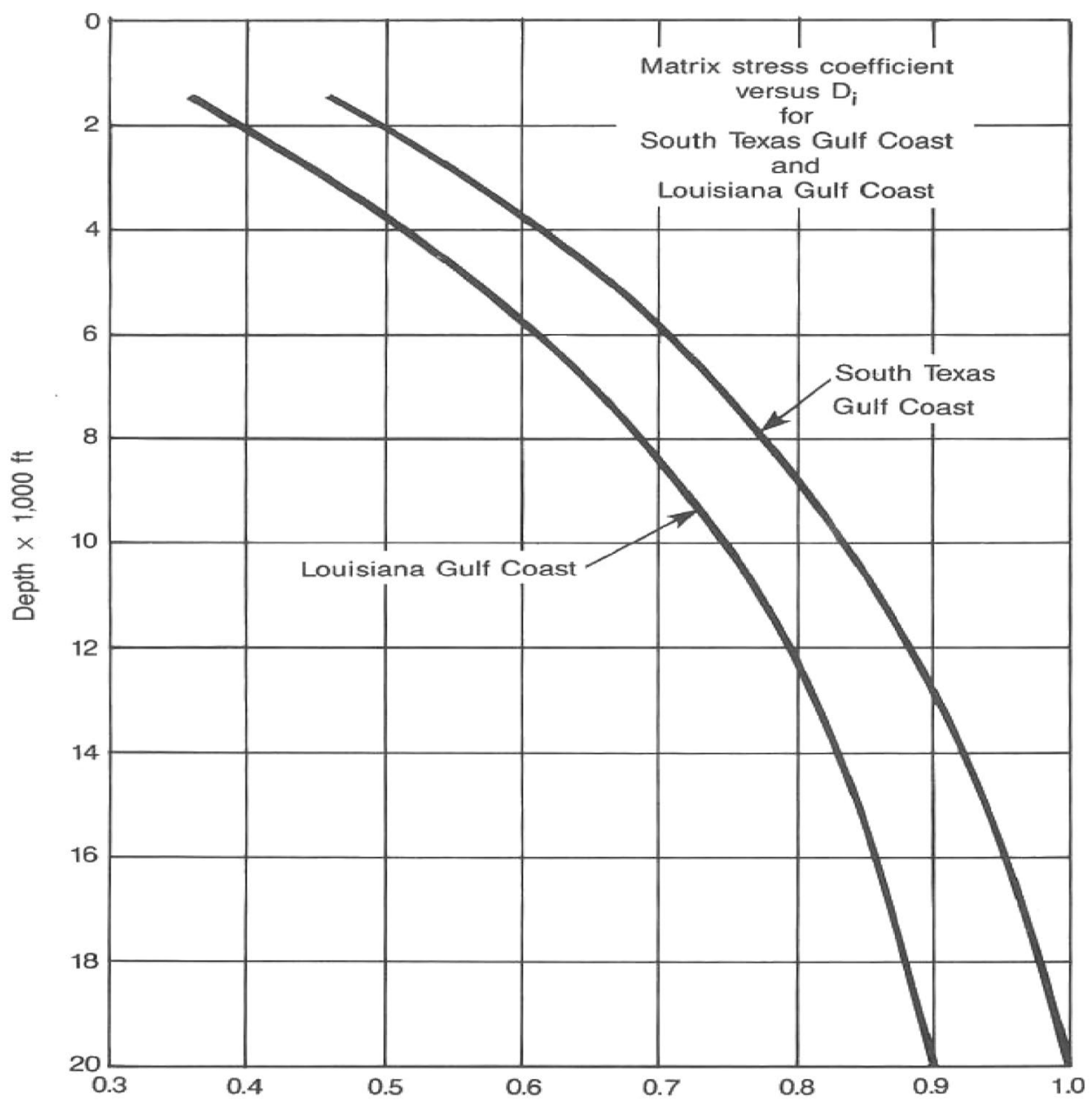

$\frac{P_{\mathrm{f}}}{H}=\frac{P_{\mathrm{t}}}{H}+\left(\frac{P_{\mathrm{ov}}}{H}-\frac{P_{\mathrm{p}}}{H}\right)\left(\frac{\gamma}{1-\gamma}\right)+\left(\frac{P_{\mathrm{p}}}{H}\right)$

\section{Mud weight selection}

Median line principle is used for the selection of appropriate mud weight so that no formation fluid loss and no formation damage accrued with maintaining hydrostatic pressure for all depths. In the median line, principle mud weight is the average pressure of pore pressure and fracture pressure. Mud weight should be selected with an additional $0.3 \mathrm{ppg}$ as the swab pressure, $0.3 \mathrm{ppg}$ as the surge pressure and $0.2 \mathrm{ppg}$ as a safety factor.

\section{Target depth selection and casing shoe depth selection}

Alam (1989) showed that the sediments are mainly Middle Miocene to Holocene in age and include up to $10,000 \mathrm{~m}$ of coarse to fine clastic (Siwalik group) that are derived directly from the Himalayan uplift and are essential of fluvial molasses characteristics. The north margin of this fore deep is strongly folded and faulted.

From the stratigraphy (Fig. 3), it is found that Middle Bhuban encountered around $3000 \mathrm{~m}$ to the $6000 \mathrm{~m}$ depth. Though the Middle Bhuban is exposed on the Tulamura anticline, it is decided to select the target depth $5600 \mathrm{~m}$ as the pore pressure accelerates to the higher magnitude at these depths which may be due to the hydrocarbon presence. Besides, the Lower Bhuban strata penetrated in the deepest well in Rokhia have good source rating, capable of generating gas and condensate.

Also, it is better to design an exploratory well for deeper depths not only to explore hydrocarbons but also to obtain a safe casing policy. So, the target depth for the well on the top of the anticline is selected as $18500 \mathrm{ft}$ (approximately $5630 \mathrm{~m})$.

After target depth selection, casing shoe depth and the number of casings are selected by the bottom-to-top approach from drilling operation manual for Oil and Natural Gas Corporation (Dehradun 2002). Mud weight is also 
selected based on the above median line principle by using surge, swab and safety margin. First, shoe depth is selected for production casing at the target depth (Gabolde and Nguyen 2006).

Any wells will not be drilled with a single type of casing. Selecting casing seats for pressure control purposes starts with knowing geological conditions such as formation pressures and fracture gradients. This information is generally available within an acceptable degree of accuracy.

The second casing is selected as intermediate casing; it is between the shallowest possible depth for intermediate casing and the deepest possible setting depth for the intermediate casing.

Surface casing avoids underground blowouts to choose a depth that can competently withstand the pressures of reasonable kick conditions. First, calculate equivalent mud weight at the depth of interest and draw a graph with depth which cuts the fracture pressure at a particular depth as selected as the surface casing.

\section{Hole geometry selection}

The hole geometry selection is based on several commonly used hole geometry programs. From expected drilling condition and based on bit and casing size availability, drilling industry selects geometry programs (Gabolde and Nguyen 2006).

\section{Collapse pressure}

From the Schlumberger, oilfield glossary collapsed pressure is the pressure at which a tube, or vessel, will terribly deform as a result of differential pressure acting from outside to the inside of the vessel or tube.

The conventional approach is used for calculating collapse pressure. As shown in Eq. (11) external pressure is equal to casing annulus pressure and back up pressure is equal to zero (empty casing). Here, 1.125 is a factor of safety.
Collapse pressure $=1.125 *($ external pressure - back up pressure $)$

\section{Burst pressure}

Burst pressure is the theoretical internal pressure exerted on well casing walls. From conventional approaches for calculating burst pressure, internal pressure is due to the gas kick from the next phase. Here, 1.1 is the factor of safety.

Burst pressure $=1.1 *($ external pressure - back up pressure $)$

\section{Tension load}

The tensile load is due to the weight of the casing which is maximum at the top and minimum at the bottom without considering buoyancy force in a conventional approach. With considering buoyancy force, tensile load at the top and compressive load at the bottom are:

Tensile load $=1.8 *$ length of the casing pipe*nominal weight

\section{Kick tolerance calculation}

Kick tolerance calculation indicates the maximum kick volume that can be circulated at the time of drilling without fracturing the previous casing shoe at the maximum drill pipe shut-in pressure (DPSIP), and additional mud weight is required to counter the kick. Kick tolerance curve is shown in terms of plotting the kick volume v/s depth or drilling pipe depth or kick volume v/s maximum DPSIP.

$(V)=(\mathrm{Ca}) *\left(H_{\max }\right)$
Table 1 Predicted pore pressure gradient and RFT pressures gradient at Tulamura

\begin{tabular}{llll}
\hline Well name & $\begin{array}{l}\text { Overpressure starts } \\
\text { at (m) }\end{array}$ & $\begin{array}{l}\text { Number of CDP match } \\
\text { with RFT (flank) }\end{array}$ & $\begin{array}{l}\text { Number of CDP } \\
\text { match with RFT } \\
\text { (synclinal) }\end{array}$ \\
\hline Agartala Dome (Ad-6) & 2500 & 1 & 2 \\
Ambasa N Trend & 3200 & 4 & 2 \\
Kathalchari Trend & 2130 & 3 & 1 \\
Kubal & 1800 & - & 3 \\
Masimpur-3 & 2500 & 3 & 1 \\
Rokhia Structure-Ro1 & 2300 & 4 & 4 \\
Tichna Structure-Ti1 & 2400 & 1 & 4 \\
Ad-4 Trend & 3000 & 1 & 1 \\
\hline
\end{tabular}


$\mathrm{Ca}(\mathrm{bbl} / \mathrm{ft})=\frac{\left(\text { hole size }(\text { in })^{2}-\text { drill pipe size }(\text { in })^{2}\right)}{1029.4}$

$H_{\max }=\frac{\left(P_{\mathrm{fg}}-M_{\mathrm{w}}\right) * \mathrm{TVD}-\left(P_{\mathrm{pg}}-M_{\mathrm{w}}\right) * \mathrm{TVD}}{\left(M_{\mathrm{w}}-\rho_{\mathrm{k}}\right)}$

where $V$ is the influx volume at the shoe, $\mathrm{Ca}$ is the capacity of the open hole annuals, $H_{\max }$ is the maximum height of a gas bubble, $M_{\mathrm{w}}$ is the mud weight, $\rho_{k}$ is the influx density $=1.9 \mathrm{ppg}$, TVD is the true vertical depth, $P_{\mathrm{fg}}$ is the facture pressure gradient at the current casing shoe, $P_{\mathrm{pg}}$ is the pore pressure gradient at the next target depth.

Influx volume at the bottom is calculated by Boyles's law from calculated influx volume at the shoe:

$V_{1}=V_{\text {shoe }} \times \frac{P_{\mathrm{P}, \text { shoe }}}{P_{\mathrm{P}}}$

\section{Result and discussions}

\section{Pore pressure prediction}

Seismic data were used as an input for pore pressure prediction. Overburden pressure that starts at $1240 \mathrm{~m}$ in section A (syncline) and $2300 \mathrm{~m}$ in section B (anticline) on Tulamura is shown in Table 1.

Pore pressure (PP) predicted by new method indicates results up to the basement rock (i.e. up to $6000 \mathrm{~m}$ depth).
Basement rock is normally metamorphic or igneous below sedimentary basins and sedimentary rock formation. It is significant to select target depth is up to sedimentary formation because basement does not have a pore. In Tulamura anticline, we focused up to depth of $6000 \mathrm{~m}$, as the sedimentary rock is encountered up to that depth. In this study, $V_{\mathrm{rms}}=V_{\mathrm{avg}}$ is the first equation assumed for pore pressure prediction. This assumption is valid only for shallow depth (6000 m).

All CDPs for flank and synclinal sections are used as input data to calculate pore pressure by new method and modified Eaton's equation. Predicted pore pressure at different CDPs is compared with existing offset well repeat formation tester (RFT) pressure data for validation. Totally, 14 RFT pressure data from offset wells are considered for comparison with predicted pore pressure from seismic data. Out of 14 offset wells, 8 of them have overpressure.

Overpressure starts for Rokhia structure at the depth of $2300 \mathrm{~m}$. Here, red colour indicates the RFT pressure gradient with respect to depth. Blue colour indicates a pore pressure gradient by modified Eaton's equation, and green colour indicates a pore pressure gradient by the new method. Pore pressure gradient predicted by new method and modified Eaton's equation is matched by the RFT pressure gradient data. Overpressure gradient is constant nearly $8.13 \mathrm{ppg}$ up to the normal depth. After the normal depth, $2300 \mathrm{~m}$ for Rokhia structure pore pressure gradually increased 19.5 ppg up to the depth of $6000 \mathrm{~m}$. Comparatively, it has been observed that pore pressure gradient trend predicted by new method is better matched with RFT pressure gradient on
Fig. 6 Variable Poisson's ratio with depth as proposed by Eaton (1969)

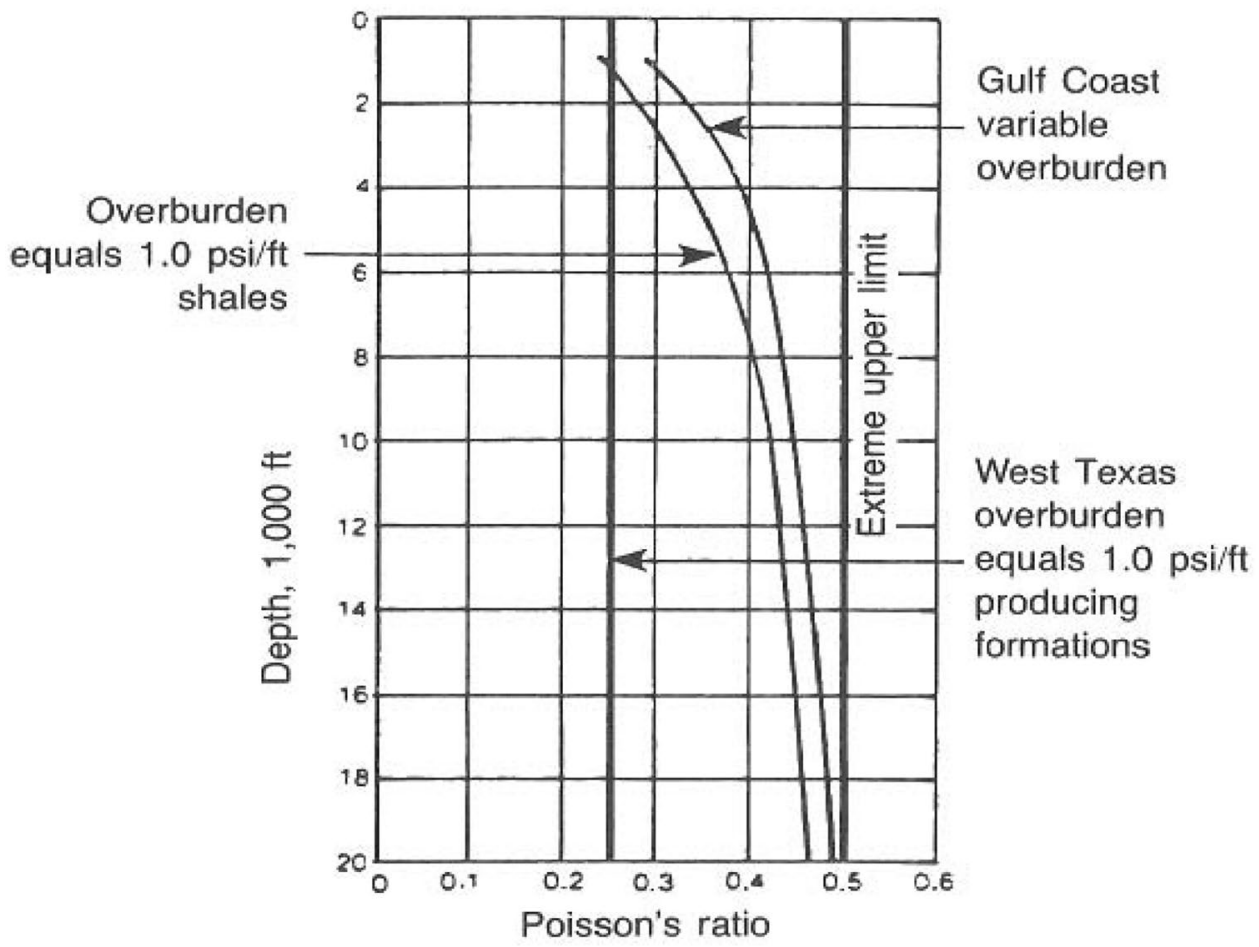


Rokhia structure than pore pressure gradient predicted by modified Eaton's method.

In Fig. 7, details of comparisons of pore pressure gradient predicted by new method and modified Eaton's method along with RFT pressure gradients of offset wells with respect to the depth are displayed for Tichna structure. Overpressure starts in Tichna structure from the depth $2400 \mathrm{~m}$ to the depth of $6000 \mathrm{~m}$. Pore pressure predicted by the new method and modified Eaton's method is $8.13 \mathrm{ppg}$ up to the normal depth of $2400 \mathrm{~m}$. Here, an excellent match between the RFT pressure gradient with pore pressure gradient by a new method and modified Eaton's method is observed for Tichna structure.

The above two comparisons on the top of Tulamura anticline show that pore pressure gradient predicted by the new method is excellently matched with RFT offset well data. It signifies that our new method is working properly for the prediction of pore pressure from seismic velocity on the top of Tulamura anticline, Tripura. The details of comparisons of the pore pressure gradient (PPG) by new method and modified Eaton's method for different CDPs along with RFT pressure gradient data are displayed in Table 1.

\section{Well design based on new method}

To design a safe and economical well on the top of Tulamura anticline, Tripura, a set of seismic profiles with seismic velocity data and two-way travel time are implemented in this research work. Details of methodology and theory are discussed in methodology section. The CDPs of both syncline and flank sections are considered as input data to design a safe well on Tulamura. The main parameters for that purpose are discussed in detail in the following subsections.

\section{Pore pressure prediction}

Table 2 displays the calculated density, overburden pressure, overburden pressure gradient, pore pressure and pore pressure gradient. The overburden pressure gradient is increased up to the shallow depth and then becomes constant about 20 to $21 \mathrm{ppg}$ for all depths. Normal hydrostatic pressure gradient becomes constant 8.13 ppg for all the depths, and pore pressure gradient predicted by new method is constant up to the normal compaction depth $(8000 \mathrm{ft})$ and then suddenly increased due to the possible hydrocarbon accumulation and high formation pressure due to Lower Bhuban formation above the depth of $8000 \mathrm{ft}$. The details of pore pressure regime are shown in Fig. 8.

\section{Fracture pressure prediction}

The fracture pressure estimated using pore pressure as input values is given in Table 3. The fracture pressure is showing the lowest by Hubbert's equations apart from all equations; fracture pressure estimated by Eaton's and modified Eaton's methods gives more readable value because of the variable Poisson ratio. Complex regions like the Tulamura where normal faults are frequent than horizontal stress ratio are not homogeneous; Eaton's equation works well with variable stress ratio. Tulamura structure is an anticline which has undergone folding and stress

Table 2 Pore pressure prediction by a new method

\begin{tabular}{|c|c|c|c|c|c|c|c|c|}
\hline Time (msec) & $\begin{array}{l}\text { RMS } \\
\text { velocity } \\
(\mathrm{m} / \mathrm{s})\end{array}$ & $\begin{array}{l}\text { Interval } \\
\text { velocity } \\
(\mathrm{m} / \mathrm{s})\end{array}$ & DEPTH (ft) & Density (g/cc) & $\begin{array}{l}\text { Overburden } \\
\text { pressure }(\mathrm{kg} / \\
\left.\mathrm{cm}^{2}\right)\end{array}$ & $\begin{array}{l}\text { Overburden } \\
\text { pressure gradient } \\
\text { (ppg) }\end{array}$ & $\begin{array}{l}\text { Pore pressure by } \\
\text { new method }(\mathrm{kg} / \\
\left.\mathrm{cm}^{2}\right)\end{array}$ & $\begin{array}{l}\text { Pore pressure } \\
\text { gradient by new } \\
\text { method (ppg) }\end{array}$ \\
\hline 36 & 1829 & 0.00 & 108.01 & _ & 3.29 & 8.35 & _ & _ \\
\hline 149 & 1900 & 1922.07 & 464.40 & 2.10 & 26.13 & 15.41 & 14.21 & 8.38 \\
\hline 312 & 2060 & 2196.08 & 1054.33 & 2.19 & 65.45 & 17.00 & 32.25 & 8.38 \\
\hline 433 & 2285 & 2782.45 & 1623.04 & 2.33 & 105.84 & 17.85 & 49.65 & 8.38 \\
\hline 876 & 2594 & 2863.99 & 3727.60 & 2.35 & 256.37 & 18.83 & 114.02 & 8.38 \\
\hline 1068 & 2730 & 3279.70 & 4782.87 & 2.42 & 334.34 & 19.14 & 146.30 & 8.38 \\
\hline 1273 & 2885 & 3585.72 & 6024.61 & 2.47 & 427.92 & 19.45 & 184.28 & 8.38 \\
\hline 1561 & 3080 & 3824.63 & 7886.94 & 2.51 & 570.23 & 19.80 & 241.25 & 8.38 \\
\hline 1712 & 3205 & 4288.78 & 9000.92 & 2.57 & 657.33 & 20.00 & 415.09 & 12.63 \\
\hline 2163 & 3502 & 4452.59 & $12,425.90$ & 2.58 & 927.07 & 20.43 & 738.40 & 16.27 \\
\hline 2410 & 3573 & 4143.09 & $14,125.54$ & 2.55 & 1059.08 & 20.53 & 910.79 & 17.65 \\
\hline 2974 & 3668 & 4048.91 & $17,894.74$ & 2.54 & 1350.47 & 20.66 & 1221.94 & 18.70 \\
\hline 3517 & 3757 & 4211.22 & $21,675.47$ & 2.56 & 1645.05 & 20.78 & 1512.03 & 19.10 \\
\hline 4044 & 3816 & 4188.52 & $25,314.80$ & 2.55 & 1928.31 & 20.86 & 1786.31 & 19.32 \\
\hline 4959 & 3899 & 4246.45 & $31,717.75$ & 2.56 & 2428.02 & 20.96 & 2259.25 & 19.50 \\
\hline
\end{tabular}




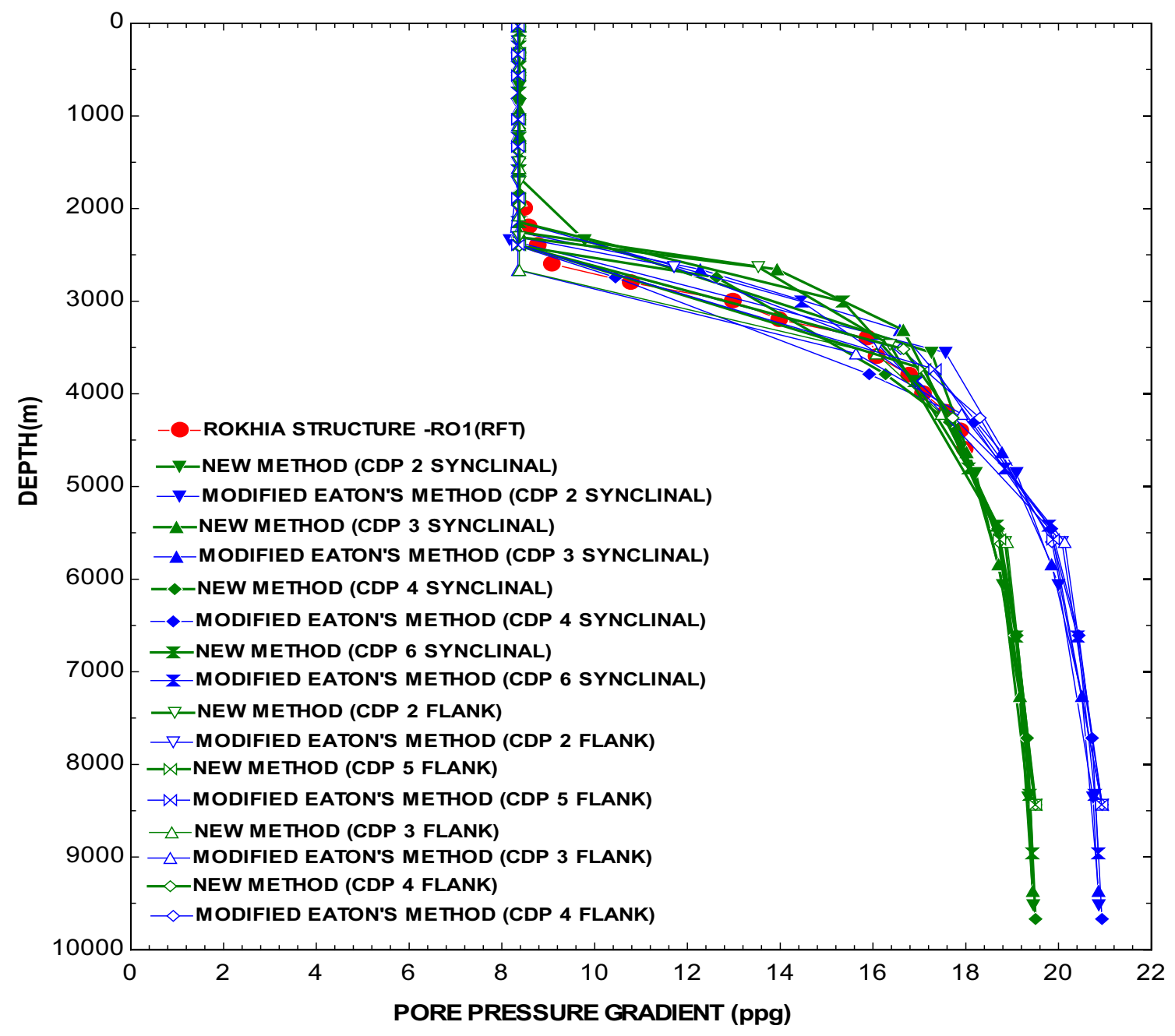

Fig. 7 RFT and predicted pore pressure by new method and modified Eaton's method. (Rokhia structure—RO1)

anisotropy so tectonic stress correction is required. Therefore, using variable Poisson's ratio, Eaton and modified Eaton's equations give the best result after tectonic correction. For a geologically complex region like Tulamura, modified Eaton's method is more suitable. The comparative fracture pressures estimated by various methods on Tulamura are shown in Table 3.

All units are taken on FPS (foot-pound-second) measurement system for simplicity to design a well and selection of casing effortlessly. Table 2 indicates the fracture pressure in psi with respect to depth on the top of Tulamura anticline. Calculated fracture pressure by modified Eaton's equation, Eaton's equation, Hubbert and Willis's equation and Matthews and Kelly's equation is shown in Table 2 and Fig. 9. All calculations are based on the pore pressure predicted by the new method.

Pressure gradient (ppg) v/s depth (ft) is given in Fig. 9 and Fig. 10 shows all fracture pressure gradient behaviours with respect to depth. Here, black colour indicated pore pressure gradient by new method, fracture pressure gradient by Hubbert and Willis's equation (blue) lowest compare to all fracture pressure gradients because constant Poisson's ratio $(0.25)$ is used. Fracture pressure gradient by Matthews and Kelly's equation (red) is very high at higher depth due to the use of matrix stress coefficient (0.33). Fracture pressure gradient by Eaton's equation (green) is given better result but required tectonic correction. Fracture pressure gradient by modified Eaton's method is given by purple colour. Continuous line indicates fracture pressure gradient estimated using pore pressure predicted by new method, and dotted line indicates fracture pressure gradient estimated by using pore pressure predicted by modified Eaton's method. This graph further plays an important role to estimate mud weight selection and casing selection. 
Table 3 Fracture pressure on the Tulamura anticline using pore pressure by the proposed new equation

\begin{tabular}{|c|c|c|c|c|c|c|}
\hline DEPTH (ft) & $\begin{array}{l}\text { Overburden } \\
\text { pressure Pob } \\
\text { (psi) }\end{array}$ & $\begin{array}{l}\text { Pore pressure PP } \\
(\mathrm{psi})\end{array}$ & $\begin{array}{l}\text { Fracture pressure by } \\
\text { Hubbert and Willis } \\
\text { PFH (psi) }\end{array}$ & $\begin{array}{l}\text { Fracture pressure by } \\
\text { Matthews and Kelly } \\
\text { PFM (psi) }\end{array}$ & $\begin{array}{l}\text { Fracture pressure } \\
\text { by Eaton's equation } \\
\text { PFE (psi)) }\end{array}$ & $\begin{array}{l}\text { Fracture pressure } \\
\text { by Modified Eaton } \\
\text { PFME (psi) }\end{array}$ \\
\hline 108.01 & 46.87 & - & - & - & - & - \\
\hline 464.40 & 372.10 & 201.53 & 258.87 & 326.28 & 270.63 & 326.68 \\
\hline 1054.33 & 931.86 & 457.54 & 616.73 & 769.78 & 654.74 & 810.73 \\
\hline 1623.04 & 1506.85 & 704.34 & 973.51 & 1209.12 & 1046.41 & 1310.41 \\
\hline 3727.60 & 3650.09 & 1617.63 & 2298.95 & 2840.08 & 2562.54 & 3231.36 \\
\hline 4782.87 & 4760.12 & 2075.58 & 2975.35 & 3669.67 & 3374.63 & 4258.09 \\
\hline 6024.61 & 6092.59 & 2614.45 & 3780.03 & 4654.61 & 4373.84 & 5518.56 \\
\hline 7886.94 & 8118.66 & 3422.63 & 4996.08 & 6141.02 & 5948.37 & 7494.04 \\
\hline 9000.92 & 9358.83 & 4889.54 & 7059.54 & 9029.50 & 7825.05 & 8963.20 \\
\hline $12,425.90$ & $13,199.24$ & $10,285.84$ & $11,408.40$ & $14,912.73$ & $12,150.67$ & $13,037.13$ \\
\hline $14,125.54$ & $15,078.66$ & $13,356.73$ & $13,671.22$ & $17,993.72$ & $14,307.76$ & $15,004.44$ \\
\hline $17,894.74$ & $19,227.43$ & $18,462.25$ & $18,007.40$ & $23,806.53$ & $18,653.12$ & $19,257.03$ \\
\hline $21,675.47$ & $23,421.52$ & $23,031.38$ & $22,158.95$ & $29,334.83$ & $22,912.33$ & $23,537.30$ \\
\hline $25,314.80$ & $27,454.46$ & $27,280.97$ & $26,106.58$ & $34,584.13$ & $26,985.85$ & $27,653.05$ \\
\hline $31,717.75$ & $34,569.03$ & $34,526.52$ & $32,967.17$ & $43,689.26$ & $34,135.84$ & $34,928.76$ \\
\hline
\end{tabular}

\section{Optimal drilling mud weight selection}

It is very critical to decide proper mud weight for safe well drilling. Mud weight should be varying with depth at drilling time. For maintaining hydrostatic pressure at a time of drilling, mud weight selection is the main decision variable. Hydrostatic pressure must be maintained between pore pressures and fracture pressure for safe drilling. Optimum mud weight is selected using the median line principle and shown in Fig. 11. In the depth v/s mud weight graph, red line indicates mud weight in ppg calculated by using the median line principle. A green colour line indicates mud weight estimated by considering surge and swab with the median line principle. Tulamura is a high pressure and temperature formation at a deep depth. Mud weight up to the normal pressure depth upto $(8000 \mathrm{ft}$ ) should be $11 \mathrm{ppg}$ to $14 \mathrm{ppg}$, but for abnormal pressure, at depth from $8000 \mathrm{ft}$ to $20,000 \mathrm{ft}$ the required mud weight is from 14 to $20 \mathrm{ppg}$ as shown in Table 4.

\section{Burst pressure, collapse pressure and casing seat selection}

A single type of casing is not used for the whole depth of well. Casing shoe depth, number of casing string, casing dimension and material are decided by casing policy selection from pore pressure gradient and fracture pressure gradient. For casing depth selection, pore pressure, fracture pressure and optimal mud weight are required. In the process of casing seat selection, shoe is set where the next formation is drilled out without fracturing casing shoe. From graphical plotting of pore pressure gradient, fracture pressure gradient against depth. This procedure is implemented bottom to top. In this paper, casing depth selection is shown in Table 5. First, $100 \mathrm{ft}$ is considered as conductor casing. Casing depth up to $6050 \mathrm{ft}, 15,500 \mathrm{ft}$ and $18,500 \mathrm{ft}$ is considered for a surface, intermediate and production casing, respectively, by the method of setting depth selection as described in theory and methodology by using pore pressure predicted by a new method.

After casing depth determination, casing dimension, nominal weight and grade are selected form calculating collapse pressure, burst pressure and tension load for each casing. For load calculation, conventional approach is used for all casings. In the conventional approach, the minimum desired safety factor for collapse 1.125 , burst 1.10 and tension 1.80 is considered.

Casing pipe property is given in Table 5 . Here, we used four casings: conductor casing, surface casing, intermediate casing and production casing. Available standard casing property from petroleum handbook data book by Adams and Charrier (1985) is selected based on casing diameter, collapse resistance and blast resistance. Tension resistance is also considered for selection parameter in this research work. Casing collapsed pressure (psi), burst pressure (psi) and casing type with respect to depth are given in Table 6.

Casing grade is selected for conductor casing up to depth of 100-150 ft and recommended with grade (k-55, $94.0 \mathrm{lbm} /$ $\mathrm{ft}$ ), surface casing up to depth of $6050 \mathrm{ft}$ with casing grade (Q-125, $92.50 \mathrm{lbm} / \mathrm{ft})$ as shown in Fig. 12. Intermediate casing $6050 \mathrm{ft}$ to $15,500 \mathrm{ft}$ with casing grade $(\mathrm{V}-150,70.30$ $\mathrm{lbm} / \mathrm{ft}$ ) in Fig. 13, and two types of production casings for the depth $0 \mathrm{ft}$ to $11,500 \mathrm{ft}$ with casing grade $(\mathrm{P}-110,38.0$

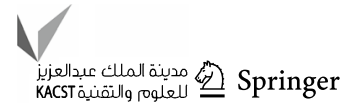




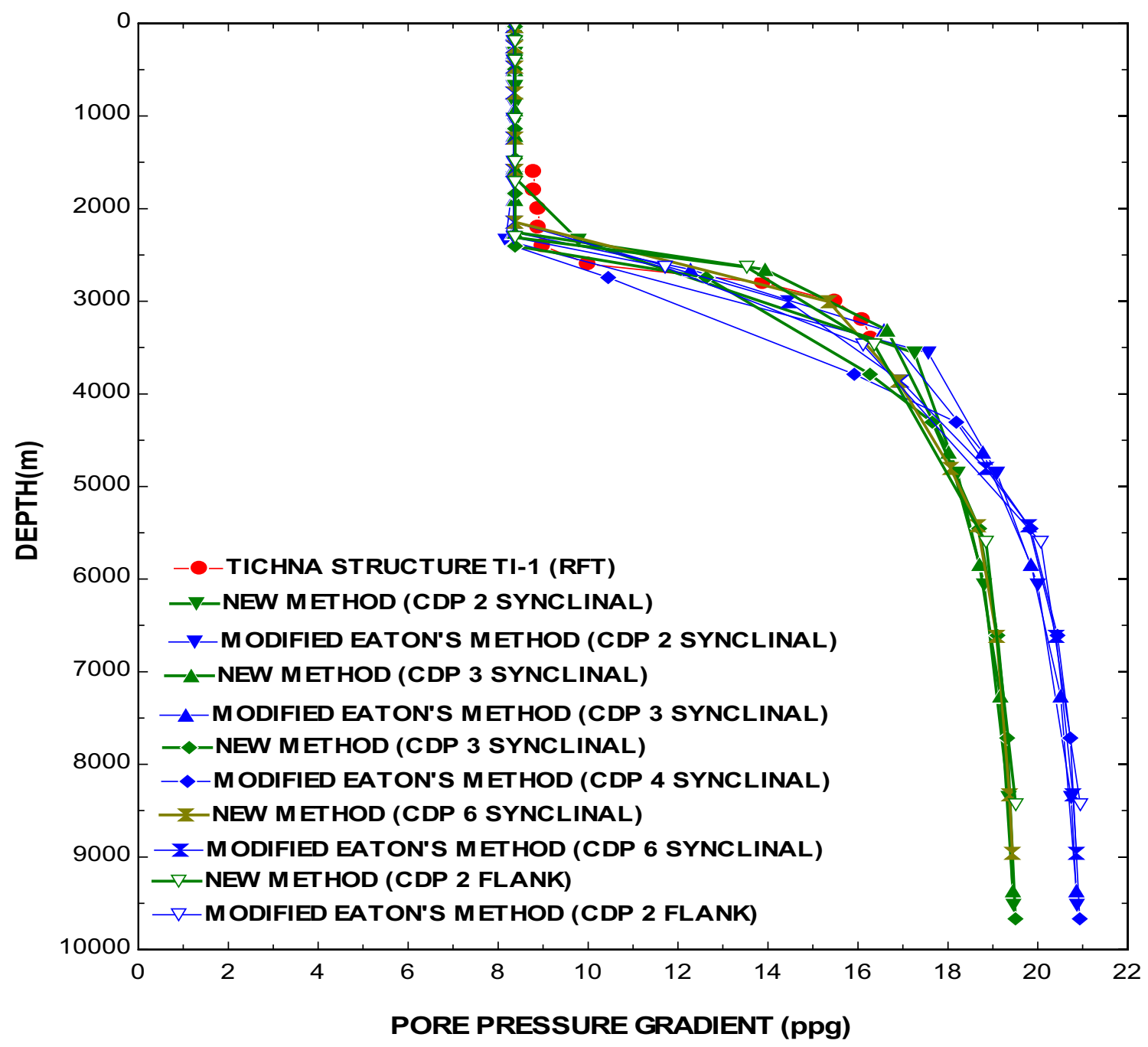

Fig. 8 RFT and predicted pore pressures by new method and modified Eaton's method. (Tichna structure Tl-1)

$\mathrm{lbm} / \mathrm{ft}$ ) and for $11,500 \mathrm{ft}$ to $18,500 \mathrm{ft}$ is grade (V-150, 42.70 $\mathrm{lbm} / \mathrm{ft}$ ) shown in Fig. 14.

Figures 12, 13 and 14 indicate casing grade selection by considering collapse and burst pressure for the surface casing, intermediate casing and production casing. Green colour indicates recommended collapse pressure in psi, red colour indicates internal burst pressure in psi, yellow colour indicates backup burst pressure in psi, and maroon colour indicates recommended resultant burst pressure in psi for casing grade selection. Blue and purple colours indicate selected casing grade for respective casing diameter.

\section{Kick tolerance calculation}

The curve shown in the drill pipe depth v/s kick volume (Fig. 15) is called a kick tolerance graph. A point above and left the side of a line is the safe zone. The point below and right side of the line is the blowout zone. The combination of drill pipe shut-in pressure and kick size gives kick tolerance in bbl. Table 7 gives the details of kick tolerance values for the top of Tulamura anticline.

For drilling up to depth $100 \mathrm{ft}$ to $6050 \mathrm{ft}$, no surface casing is required; only conductor casing is necessary. Therefore, kick volume $750 \mathrm{bbl}$ is required to control at the depth $100 \mathrm{ft}$ and up to $10 \mathrm{bbl}$ at $6050 \mathrm{ft}$. After drilled up to $6050 \mathrm{ft}$, it is advisable to install surface casing before further drilling. After conductor casing, kick volume is controlled up to 254 bbl at $6050 \mathrm{ft}$ and up to $60 \mathrm{bbl}$ at 12,500 ft. After drilled up to $12,500 \mathrm{ft}$, it is advisable to install intermediate casing. Finally, drilling up to target depth $18,500 \mathrm{ft}$. After drilled up to the $18,500 \mathrm{ft}$, two-step production casing install is ( $\mathrm{P}-110$, 


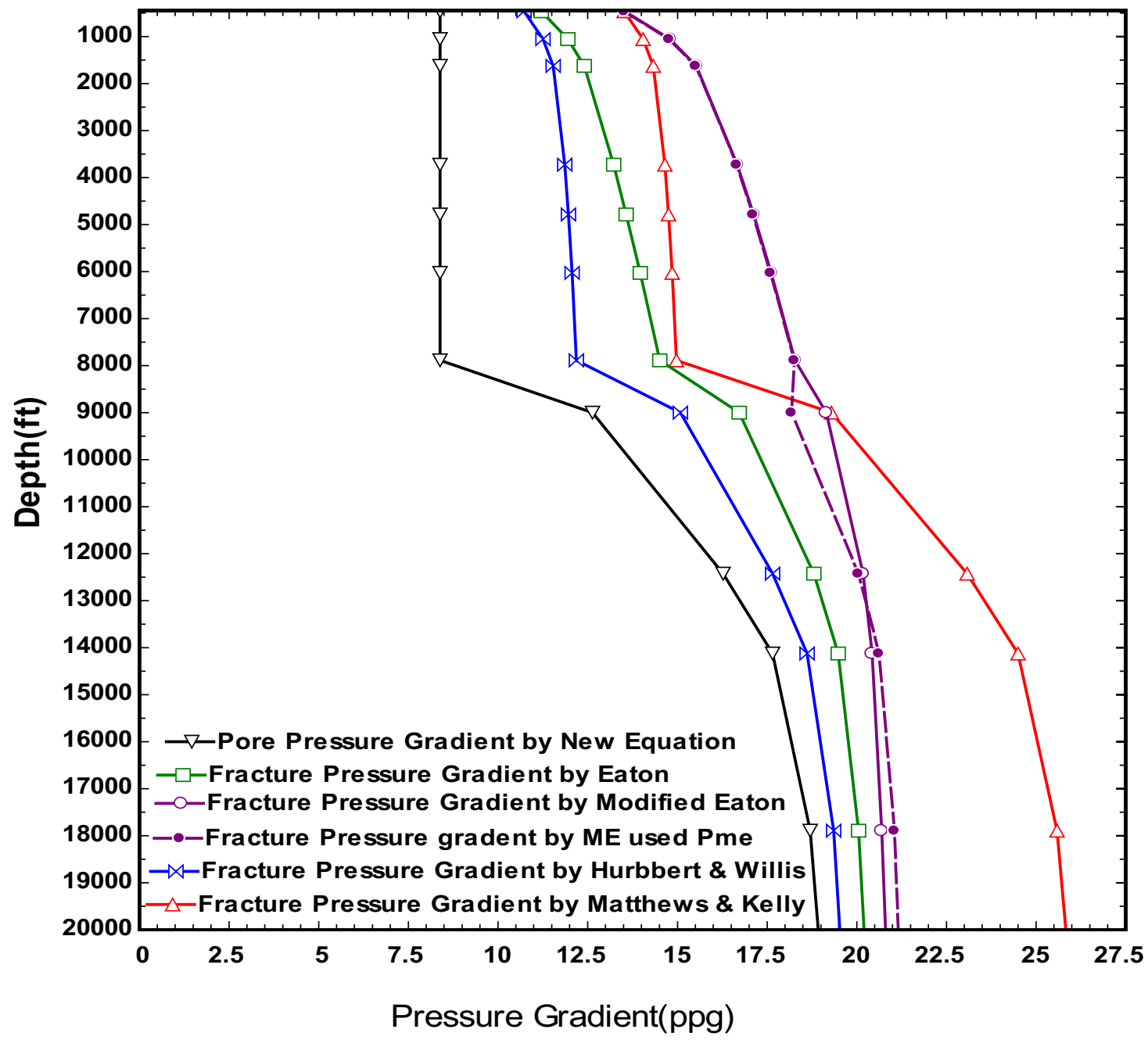

Fig. 9 Fracture pressure gradient calculated using pore pressure predicted by new method

$38.0 \mathrm{lbm} / \mathrm{ft})$ for $0-11,500 \mathrm{ft}$ and $(\mathrm{V}-150,42.70 \mathrm{lbm} / \mathrm{ft})$ for $11,500-18,500 \mathrm{ft}$.

\section{Determination of cement slurry volume for cementing}

Cement slurry volume is calculated as described in theory section. The details of volume required for all casings are shown in Table 8. Firstly, the annular capacity of the casing and an open hole in (bbl/ft) is calculated, and then, cement slurry volume for all casings is estimated. Cement slurry volume required for conductor casing is $26.28 \mathrm{bbl}$, for production casing is $748.52 \mathrm{bbl}$, for intermediate casing is $527.14 \mathrm{bbl}$ and for production casing is $1283.39 \mathrm{bbl}$. Total cement slurry volume required for the cementing operation is $2585.86 \mathrm{bbl}$.

\section{Well design base on modified Eaton's method}

\section{Pore pressure prediction}

Pore pressure prediction by modified Eaton's method required compaction trend line for velocity ratio of normal velocity to observe velocity. The normal compaction trend line is given by the equation $x=-0.000155 y+2.215$. Here, $\mathrm{x}$ indicates $\log (\Delta t)$ and $\mathrm{y}$ indicates formation depth as shown in Fig. 16.

Table 9 indicates the calculated density, overburden pressure, overburden pressure gradient, pore pressure and pore pressure gradient. An overburden pressure gradient is increased up to the shallow depth and then becomes constant about 20 to 21 ppg for all depths. Normal hydrostatic pressure gradient becomes constant $8.13 \mathrm{ppg}$ for all the depths, and pore pressure gradient by using new method is constant up to the normal compaction depth $(8000 \mathrm{ft})$ and 


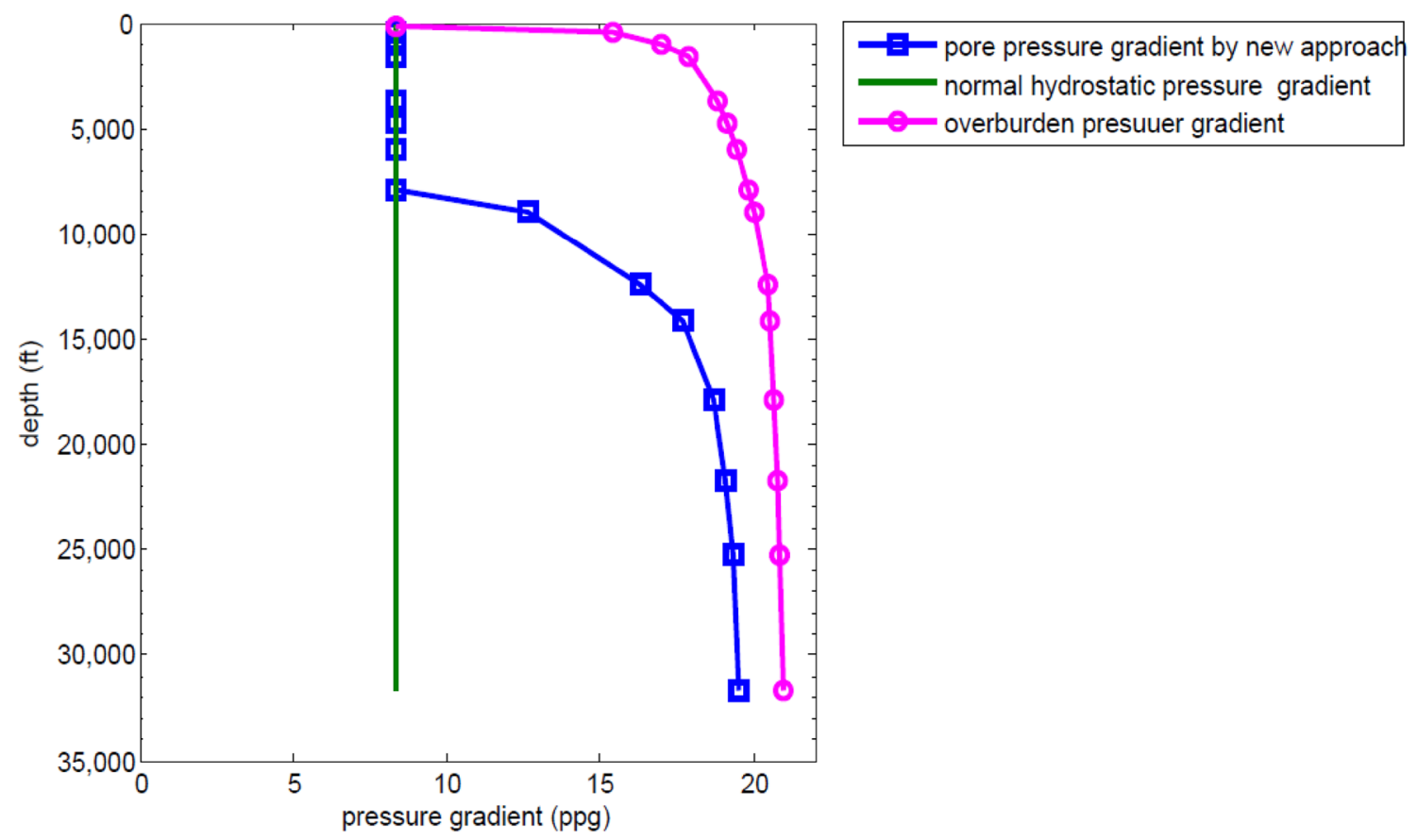

Fig. 10 Pore pressure gradient by the new method

then suddenly increased due to the hydrocarbon possibility and high formation pressure due to Lower Bhuban formation above the depth of $8000 \mathrm{ft}$. The details of pore pressure regime are shown in Figs. 16, 17.

\section{Fracture pressure prediction}

All fracture pressures are calculated by using predicted pore pressure by modified Eaton's method as input parameters.
The details of values are displayed in Table 10. In this research work, the fracture pressure calculated by Hubbert's equations is observed at the lowest values; fracture pressure estimated by Eaton and modified Eaton's equations gives more readable value because of the variable Poisson ratio (Fig. 18). Complex basins like the Tulamura structure where normal faults are frequent than horizontal stress ratio are not homogeneous; Eaton's equation works well with variable stress ratio. Tulamura structure is anticline which has

Table 4 Optimum mud weight by median line principle on the top of the Tulamura anticline

\begin{tabular}{lllllc}
\hline Depth (ft) & $\begin{array}{l}\text { Overburden pressure } \\
\text { gradient (ppg) }\end{array}$ & $\begin{array}{l}\text { Pore pressure gradient by } \\
\text { new method (ppg) }\end{array}$ & $\begin{array}{l}\text { Fracture pressure gradient } \\
\text { by modified Eaton (ppg) }\end{array}$ & $\begin{array}{l}\text { Mud pressure gradient } \\
\text { (ppg) median line }\end{array}$ & $\begin{array}{l}\text { Mud pressure gradient } \\
\text { (ppg) surge and swab }\end{array}$ \\
\hline 108.01 & 8.35 & - & - & - & - \\
464.40 & 15.41 & 8.38 & 13.52753 & 11.89175 & 12.49175 \\
1054.33 & 17.00 & 8.38 & 14.78755 & 12.68599 & 13.28599 \\
1623.04 & 17.85 & 8.38 & 15.52654 & 13.11459 & 13.71459 \\
3727.60 & 18.83 & 8.38 & 16.67064 & 13.60299 & 14.20299 \\
4782.87 & 19.14 & 8.38 & 17.12075 & 13.75718 & 14.35718 \\
6024.61 & 19.45 & 8.38 & 17.61542 & 13.91142 & 14.51142 \\
7886.94 & 19.80 & 8.38 & 18.27276 & 14.08542 & 14.68542 \\
9000.92 & 20.00 & 12.63 & 19.15018 & 16.31107 & 16.91107 \\
12425.90 & 20.43 & 16.27 & 20.17674 & 18.34895 & 18.94895 \\
14125.54 & 20.53 & 17.65 & 20.42732 & 19.09127 & 19.69127 \\
$17,894.74$ & 20.66 & 18.70 & 20.69477 & 19.67962 & 20.27962 \\
$21,675.47$ & 20.78 & 19.10 & 20.88261 & 19.93975 & 20.53975 \\
$25,314.80$ & 20.86 & 19.32 & 21.00705 & 20.08824 & 20.68824 \\
$31,717.75$ & 20.96 & 19.50 & 21.17763 & 20.23111 & 20.83111 \\
\hline
\end{tabular}


Table 5 Casing properties

\begin{tabular}{|c|c|c|c|c|c|c|c|}
\hline $\begin{array}{l}\text { Casing diam- } \\
\text { eter (inch) }\end{array}$ & $\begin{array}{l}\text { Nominal weight } \\
(\mathrm{lbm} / \mathrm{ft})\end{array}$ & Grade & $\begin{array}{l}\text { Wall thickness } \\
\text { (inch) }\end{array}$ & $\begin{array}{l}\text { Pipe body yield } \\
\text { strength } 1000 \mathrm{lbf}\end{array}$ & $\begin{array}{l}\text { Joint strength } \\
1000 \mathrm{lbf}\end{array}$ & $\begin{array}{l}\text { Collapse resist- } \\
\text { ance psi }\end{array}$ & Blast resistance psi \\
\hline $20^{\prime \prime}$ & 94.00 & K-55 & 0.438 & 1480 & 955 & 520 & 2110 \\
\hline 13 3/8" & 92.50 & Q-125 & 0.672 & 3352 & 1690 & 5950 & 10,990 \\
\hline $95 / 8^{\prime \prime}$ & 70.30 & V-150 & 0.734 & 3075 & 2185 & 18,800 & 16,680 \\
\hline 7" & 38.00 & P-110 & 0.540 & 1205 & 1087 & 15,140 & 14,850 \\
\hline 7" & 42.70 & V-150 & 0.625 & 1875 & 1514 & 24,390 & 23,440 \\
\hline
\end{tabular}

Table 6 Calculated collapse pressure and burst pressure at casing shoe depth

\begin{tabular}{lllllc}
\hline Depth (ft) & $\begin{array}{l}\text { Open hole } \\
\text { diameter (inch) }\end{array}$ & $\begin{array}{l}\text { Casing diam- } \\
\text { eter (inch) }\end{array}$ & Type of casing & $\begin{array}{l}\text { Collapse pres- } \\
\text { sure (psi) }\end{array}$ & Burst pressure (psi) \\
\hline 100 & $26^{\prime \prime}$ & $20^{\prime \prime}$ & Conductor & - & $11,809.39$ \\
6050 & $171 / 2^{\prime \prime}$ & $133 / 8^{\prime \prime}$ & Surface & 4593.16 & 9223.05 \\
15,500 & $121 / 4^{\prime \prime}$ & $95 / 8^{\prime \prime}$ & Intermediate & $16,039.4$ & 5708.74 \\
18,500 & $91 / 2^{\prime \prime}$ & $7^{\prime \prime}$ & Production & $18,181.8$ & 4558.91 \\
\hline
\end{tabular}

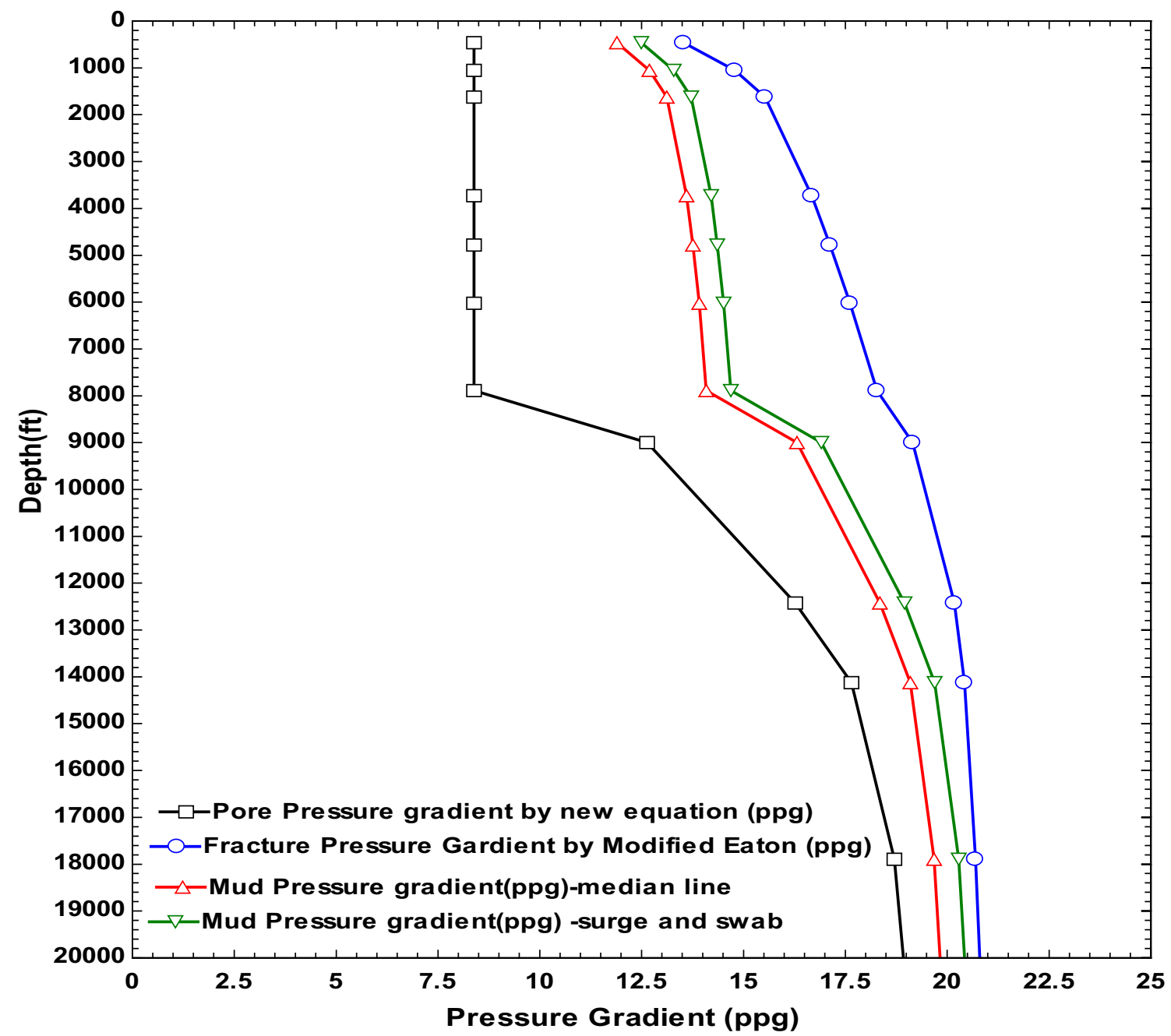

Fig. 11 Optimum mud weight on the top of the Tulamura anticline 
Fig. 12 Surface casing selection

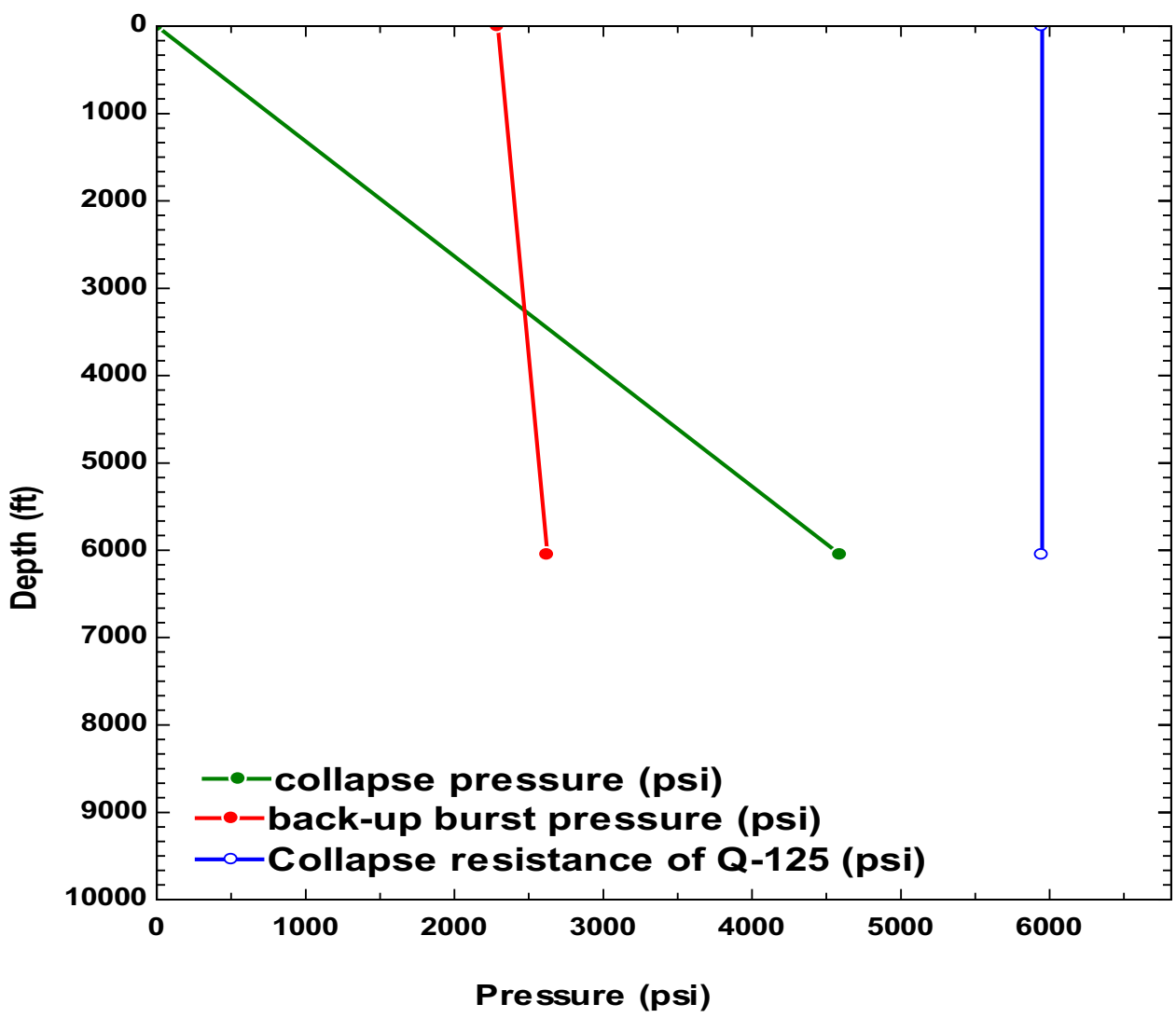

Fig. 13 Intermediate casing selection

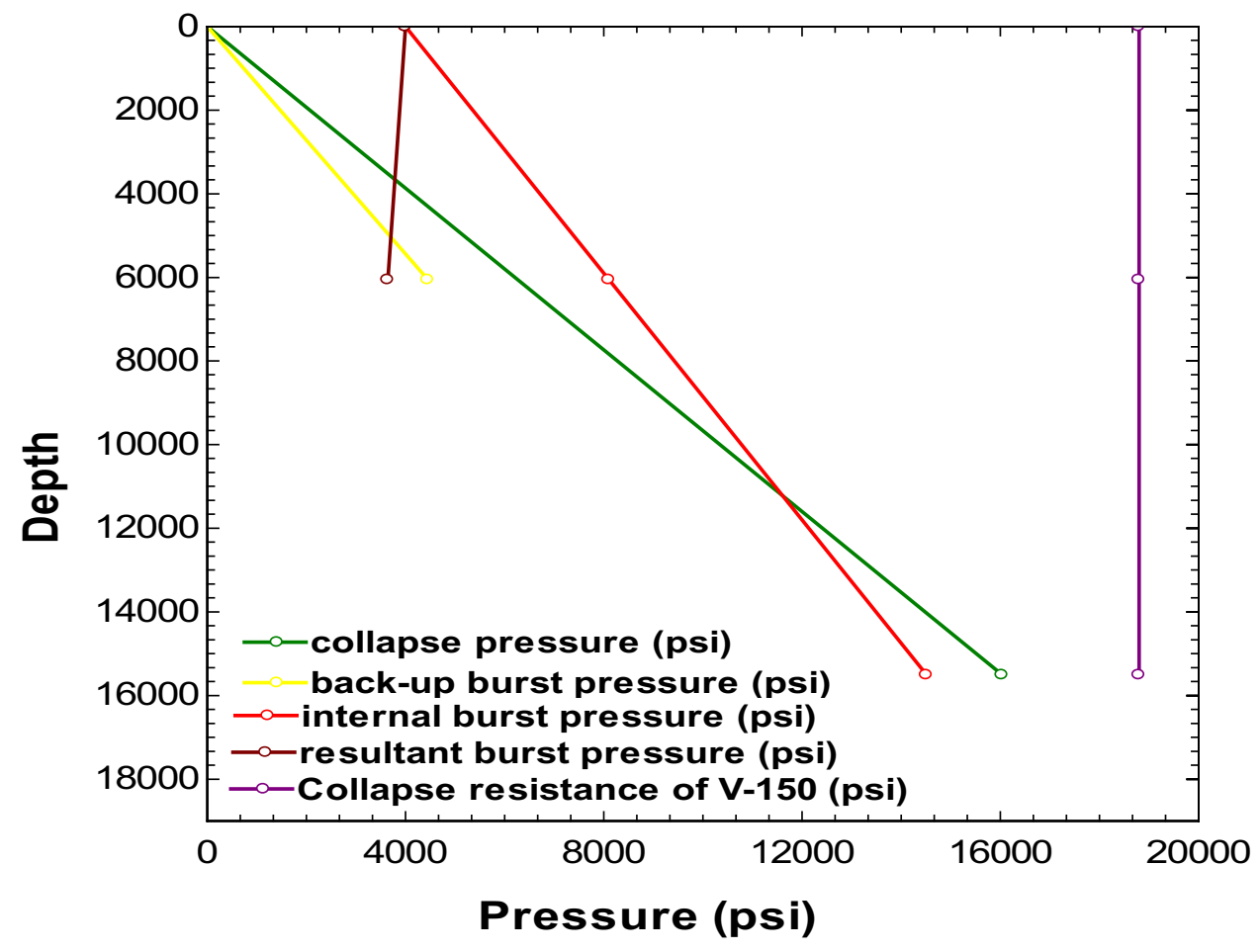


Fig. 14 Production casing selection

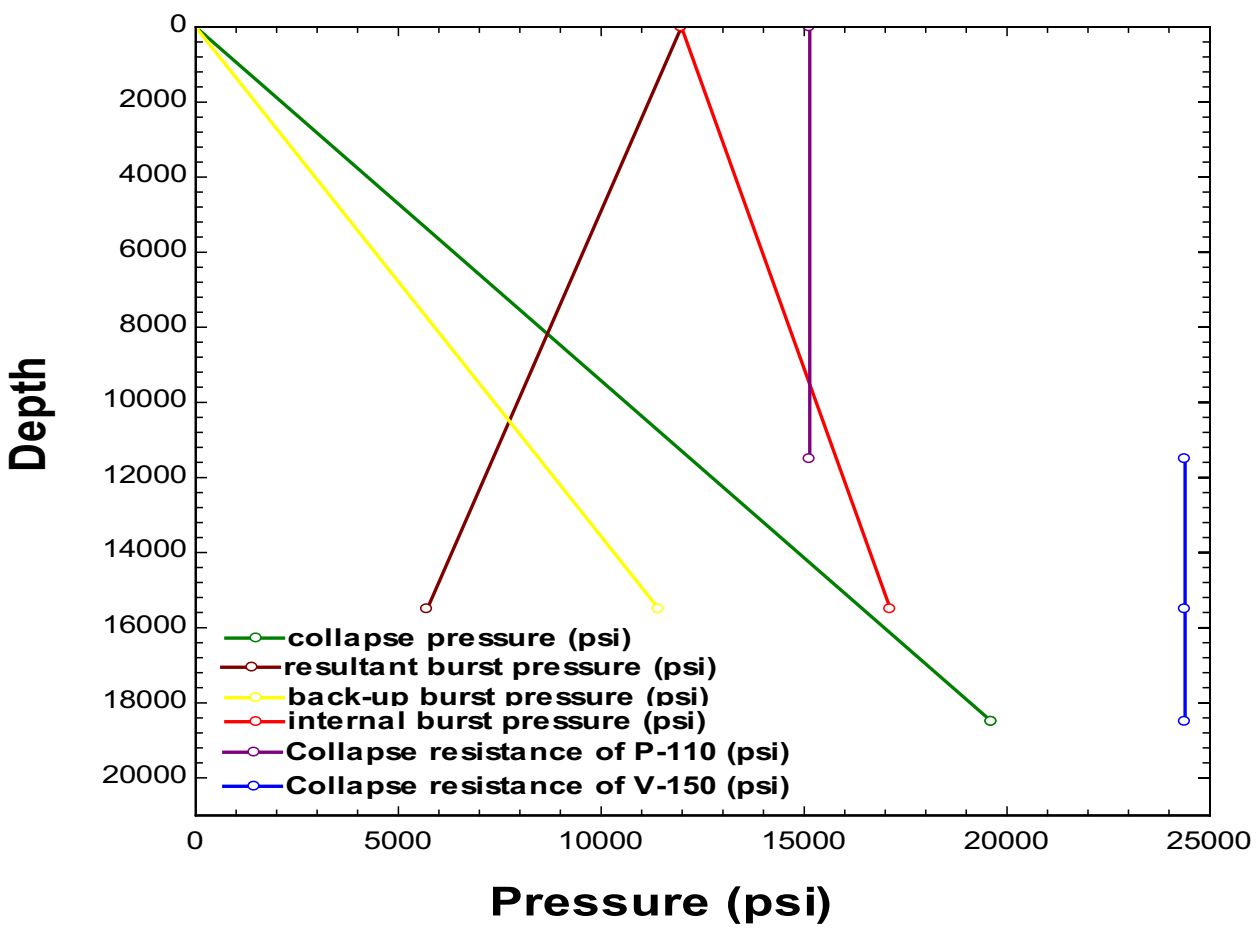

Table 7 Kick tolerance parameter calculation

\begin{tabular}{lllllllll}
\hline Depth (ft) & Casing size (in) & $\begin{array}{l}\text { GPF at } \\
\text { shoe (ppg) }\end{array}$ & $\begin{array}{l}\text { GPP at } \\
\text { shoe (ppg) }\end{array}$ & $\begin{array}{l}\text { Mud } \\
\text { weight } \\
\text { (ppg) }\end{array}$ & $\begin{array}{l}\text { Height of a } \\
\text { gas bubble (ft) }\end{array}$ & $\begin{array}{l}\text { Borehole } \\
\text { diameter (in) }\end{array}$ & $\begin{array}{l}\text { Open hole annulus } \\
\text { capacity (bbl/ft) }\end{array}$ & $\begin{array}{l}\text { The volume of } \\
\text { influx at casing shoe } \\
\text { (bbl) }\end{array}$ \\
\hline 100 & $20^{\prime \prime}$ & 13.5 & 8.38 & 12.4 & - & $26^{\prime \prime}$ & 0.6140 & - \\
6050 & $133 / 8^{\prime \prime}$ & 17.4 & 8.38 & 14.5 & 2947.30 & $171 / 2^{\prime \prime}$ & 0.2548 & 750.97 \\
15,500 & $95 / 8^{\prime \prime}$ & 20.4 & 18.00 & 19.7 & 2466.01 & $121 / 4^{\prime \prime}$ & 0.1031 & 254.24 \\
18,500 & $7^{\prime \prime}$ & 20.8 & 18.60 & 20.4 & 2386.48 & $91 / 2^{\prime \prime}$ & 0.0450 & 107.46 \\
\hline
\end{tabular}

undergone folding and stress anisotropy so tectonic stress correction which is required is given by modified Eaton's equation. For using variable Poisson's ratio, Eaton and modified Eaton's give the best result after tectonic correction. For a geologically complex region like Tulamura, modified Eaton's equation is more suitable. The comparative fracture pressures on Tulamura are shown in Table 10.

\section{Optimal drilling mud weight selection}

It is very critical to decide proper mud weight for safe well drilling. The hydrostatic pressure of drilling mud must be maintained between pore pressures and fracture pressure for safe drilling. Optimum mud weight is selected using the median line principle and shown in Fig. 19. In the depth v/s mud weight graph, red line indicates mud weight in ppg estimated by the median line principle. A green colour line indicates mud weight by considering surge and swab with the median line principle. Tulamura structure has high pressure and temperature formation at a deep depth. Mud weight up to the normal pressure formation depth at $8000 \mathrm{ft}$ the mud weight should be is the range 11-15 ppg, but for abnormal pressure, depth from $8000 \mathrm{ft}$ to $20,000 \mathrm{ft}$ the required mud weight is in the range of 15-21 ppg as shown in Table 11.

\section{Burst pressure, collapse pressure and casing seat selection}

Consider $0.3 \mathrm{ppg}$ trip margin, $0.3 \mathrm{ppg}$ surge pressure gradient and $0.2 \mathrm{ppg}$ safety factor to select all surfaces, conductors, intermediate and production casings. In this paper, casing depth selection is shown in Table 13. First, $100 \mathrm{ft}$ is considered a conductor casing. Casing depth up to $6050 \mathrm{ft}, 13,500 \mathrm{ft}$, and 18,500 ft is considered for surface, intermediate and production casing, respectively.

The conventional approach is used for the load calculation with the minimum desired safety factor for collapse 1.125 , burst 1.10 and tension 1.80 . Casing pipe property is given in Table 12. Here four types of casings: conductor 


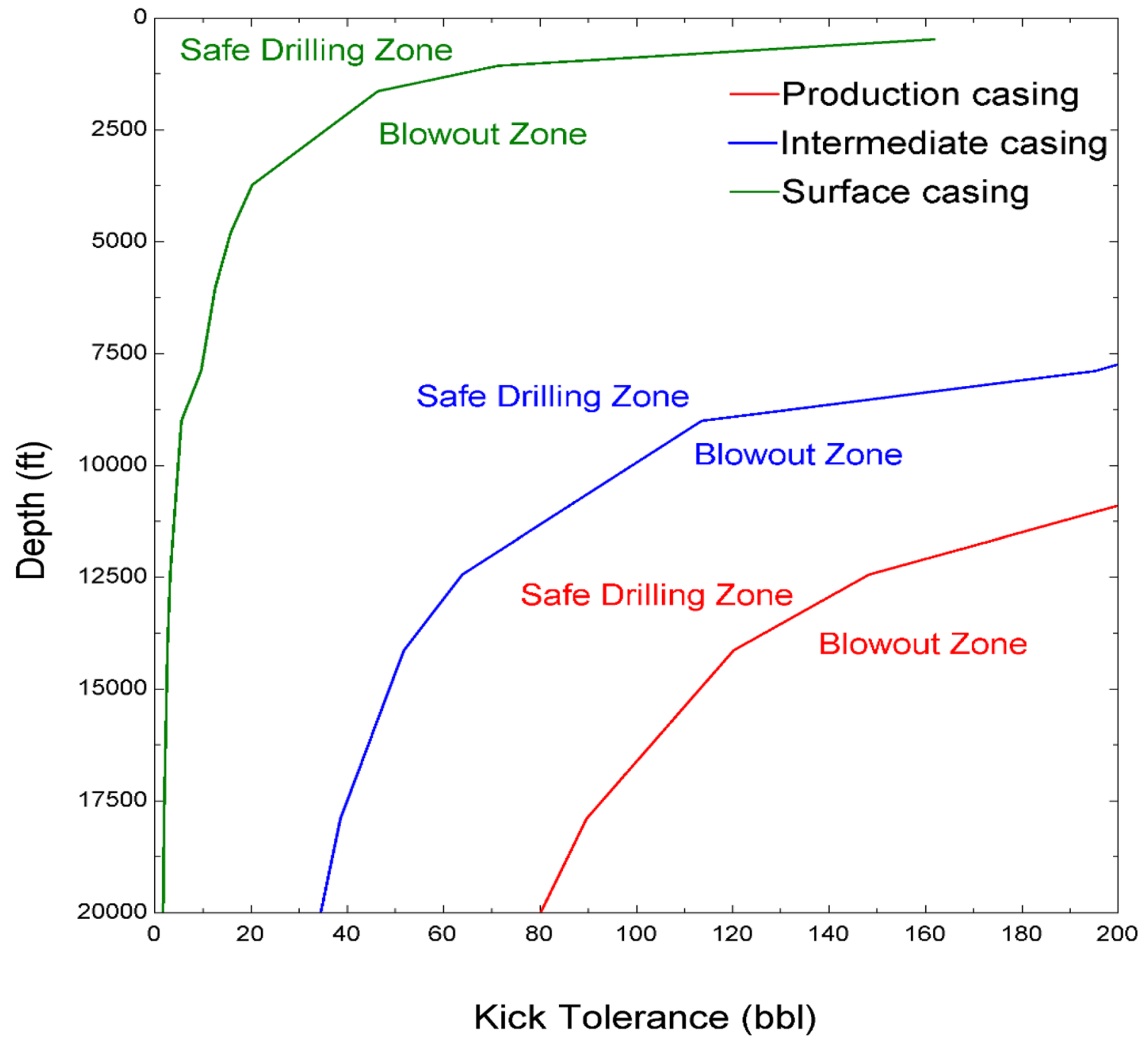

Fig. 15 Kick tolerance (bbl) versus depth (m) on the top of Tulamura anticline

Table 8 Cement slurry volume calculation for the cementing

\begin{tabular}{lllllr}
\hline Type of casing & $\begin{array}{l}\text { Open hole diam- } \\
\text { eter (inch) }\end{array}$ & $\begin{array}{l}\text { Casing diameter } \\
\text { (inch) }\end{array}$ & $\begin{array}{l}\text { Casing shoe } \\
\text { depth (ft) }\end{array}$ & $\begin{array}{l}\text { Annular capacity between open } \\
\text { hole and casing (bbl/ft) }\end{array}$ & $\begin{array}{l}\text { Cement slurry volume } \\
\text { required for cementing } \\
\text { (bbl) }\end{array}$ \\
\hline Conductor & $26^{\prime \prime}$ & $20^{\prime \prime}$ & 100 & 0.2681 & 26.81 \\
Surface & $171 / 2^{\prime \prime}$ & $133 / 8^{\prime \prime}$ & 6050 & 0.1237 & 748.52 \\
Intermediate & $121 / 4^{\prime \prime}$ & $95 / 8^{\prime \prime}$ & 15,500 & 0.0557 & 527.14 \\
Production & $91 / 2^{\prime \prime}$ & $7^{\prime \prime}$ & 18,500 & 0.0400 & 1283.39 \\
& & & & Total & 2585.86 \\
\hline
\end{tabular}

casing, surface casing, intermediate casing and production casing are used to prevent blowout during the drilling process.
Casing collapsed pressure (psi) and burst pressure (psi) with casing type with respect to depth are given in Table 13 required to design the casing pipe. 
Fig. 16 Normal compaction trend line for CDP 4 syncline

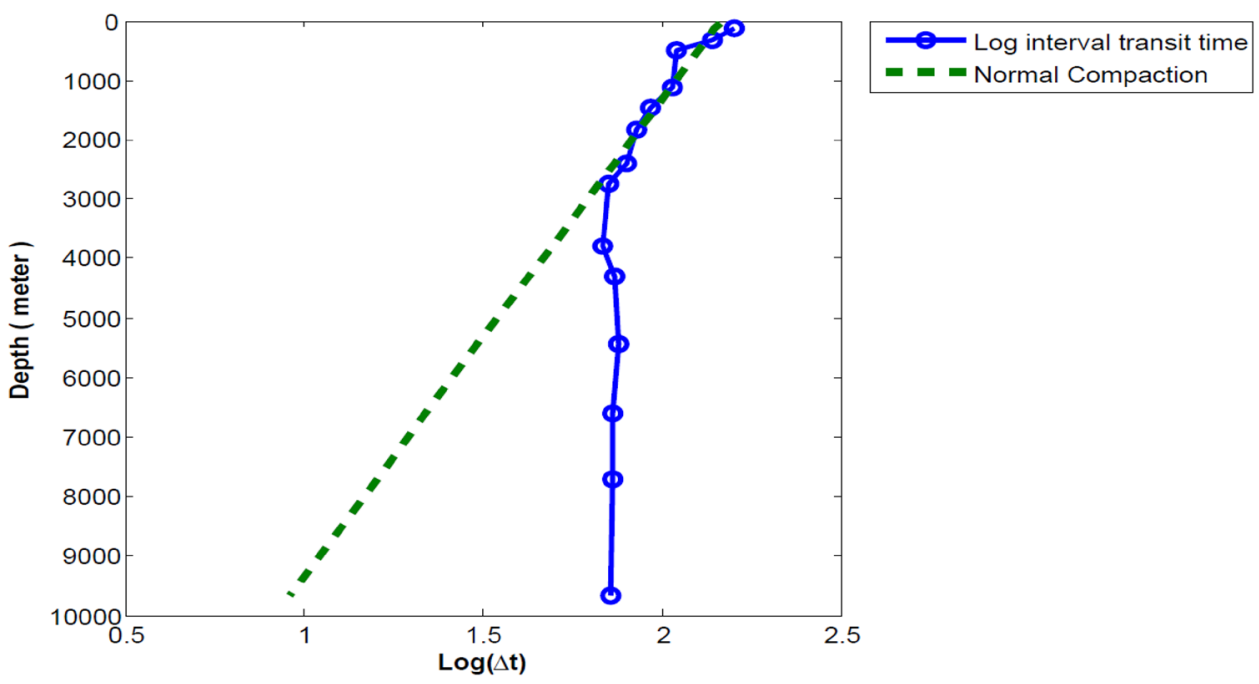

Table 9 Pore pressure prediction by modified Eaton's method

\begin{tabular}{|c|c|c|c|c|c|c|c|c|}
\hline Time (ms) & $\begin{array}{l}\text { RMS } \\
\text { velocity } \\
(\mathrm{m} / \mathrm{s})\end{array}$ & $\begin{array}{l}\text { Interval } \\
\text { velocity } \\
(\mathrm{m} / \mathrm{s})\end{array}$ & Depth (ft) & Density (g/cc) & $\begin{array}{l}\text { overburden } \\
\text { pressure }(\mathrm{kg} / \\
\left.\mathrm{cm}^{2}\right)\end{array}$ & $\begin{array}{l}\text { Overburden } \\
\text { pressure gradient } \\
\text { (ppg) }\end{array}$ & $\begin{array}{l}\text { pore pressure by } \\
\text { Eaton }\left(\mathrm{kg} / \mathrm{cm}^{2}\right)\end{array}$ & $\begin{array}{l}\text { pore pressure gradi- } \\
\text { ent by Eaton (ppg) }\end{array}$ \\
\hline 36 & 1829 & 0 & 108.01 & - & 3.29 & 8.35 & - & - \\
\hline 149 & 1900 & 1922.07 & 464.4 & 2.1 & 26.13 & 15.41 & 14.16 & 8.35 \\
\hline 312 & 2060 & 2196.08 & 1054.33 & 2.19 & 65.45 & 17 & 32.14 & 8.35 \\
\hline 433 & 2285 & 2782.45 & 1623.04 & 2.33 & 105.84 & 17.85 & 49.47 & 8.35 \\
\hline 876 & 2594 & 2863.99 & 3727.6 & 2.35 & 256.37 & 18.83 & 113.62 & 8.35 \\
\hline 1068 & 2730 & 3279.7 & 4782.87 & 2.42 & 334.34 & 19.14 & 145.78 & 8.35 \\
\hline 1273 & 2885 & 3585.72 & 6024.61 & 2.47 & 427.92 & 19.45 & 183.63 & 8.35 \\
\hline 1561 & 3080 & 3824.63 & 7886.94 & 2.51 & 570.23 & 19.8 & 240.39 & 8.35 \\
\hline 1712 & 3205 & 4288.78 & 9000.92 & 2.57 & 657.33 & 20 & 343.43 & 10.45 \\
\hline 2163 & 3502 & 4452.59 & $12,425.9$ & 2.58 & 927.07 & 20.43 & 722.44 & 15.92 \\
\hline 2410 & 3573 & 4143.09 & $14,125.54$ & 2.55 & 1059.08 & 20.53 & 938.13 & 18.18 \\
\hline 2974 & 3668 & 4048.91 & $17,894.74$ & 2.54 & 1350.47 & 20.66 & 1296.73 & 19.84 \\
\hline 3517 & 3757 & 4211.22 & $21,675.47$ & 2.56 & 1645.05 & 20.78 & 1617.65 & 20.43 \\
\hline 4044 & 3816 & 4188.52 & $25,314.8$ & 2.55 & 1928.31 & 20.86 & 1916.13 & 20.72 \\
\hline 4959 & 3899 & 4246.45 & $31,717.75$ & 2.56 & 2428.02 & 20.96 & 2425.03 & 20.93 \\
\hline
\end{tabular}

\section{Kick tolerance}

The kick tolerance curve is shown in Fig. 20. A point above and left the side of a line is the safe zone. The point below and right side of the line is the blowout zone calculation of kick v/s are shown in Table 14.

\section{Determine cement slurry volume for cementing}

The volume required for all types of casings is shown in Table 15. First, calculate the annular capacity of the casing and an open hole in (bbl/ft) and then find out cement slurry volume for all casings as given in Table 15 . Cement slurry volume for conductor casing is $26.81 \mathrm{bbl}$, production casing is $748.52 \mathrm{bbl}$, intermediate casing is $414.95 \mathrm{bbl}$ and for production casing is $1279.64 \mathrm{bbl}$. Total cement slurry volume required for the cementing operation is $2470.00 \mathrm{bbl}$. 
Fig. 17 Pore pressure by modified Eaton's method

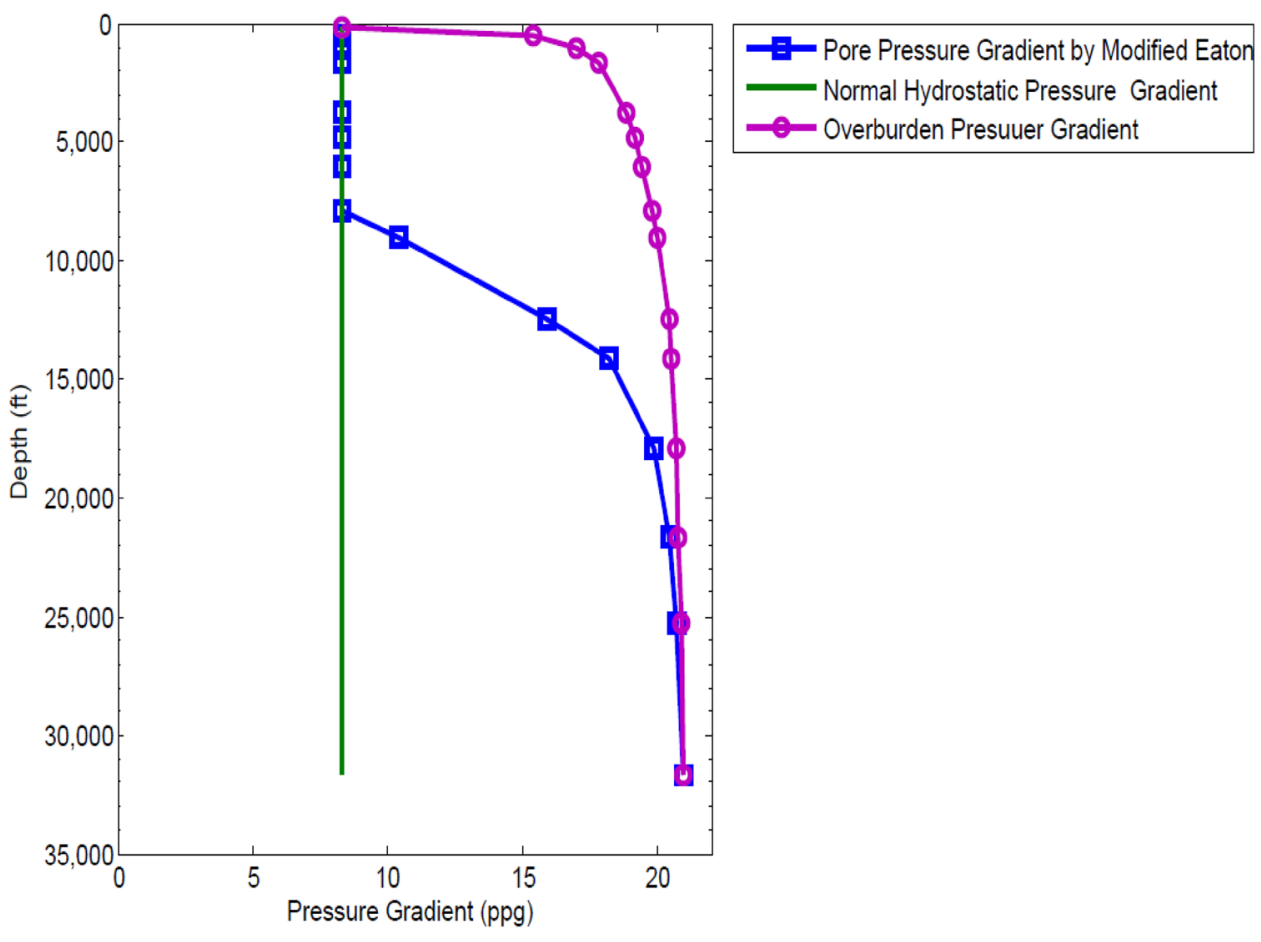

Fig. 18 Fracture pressure gradient

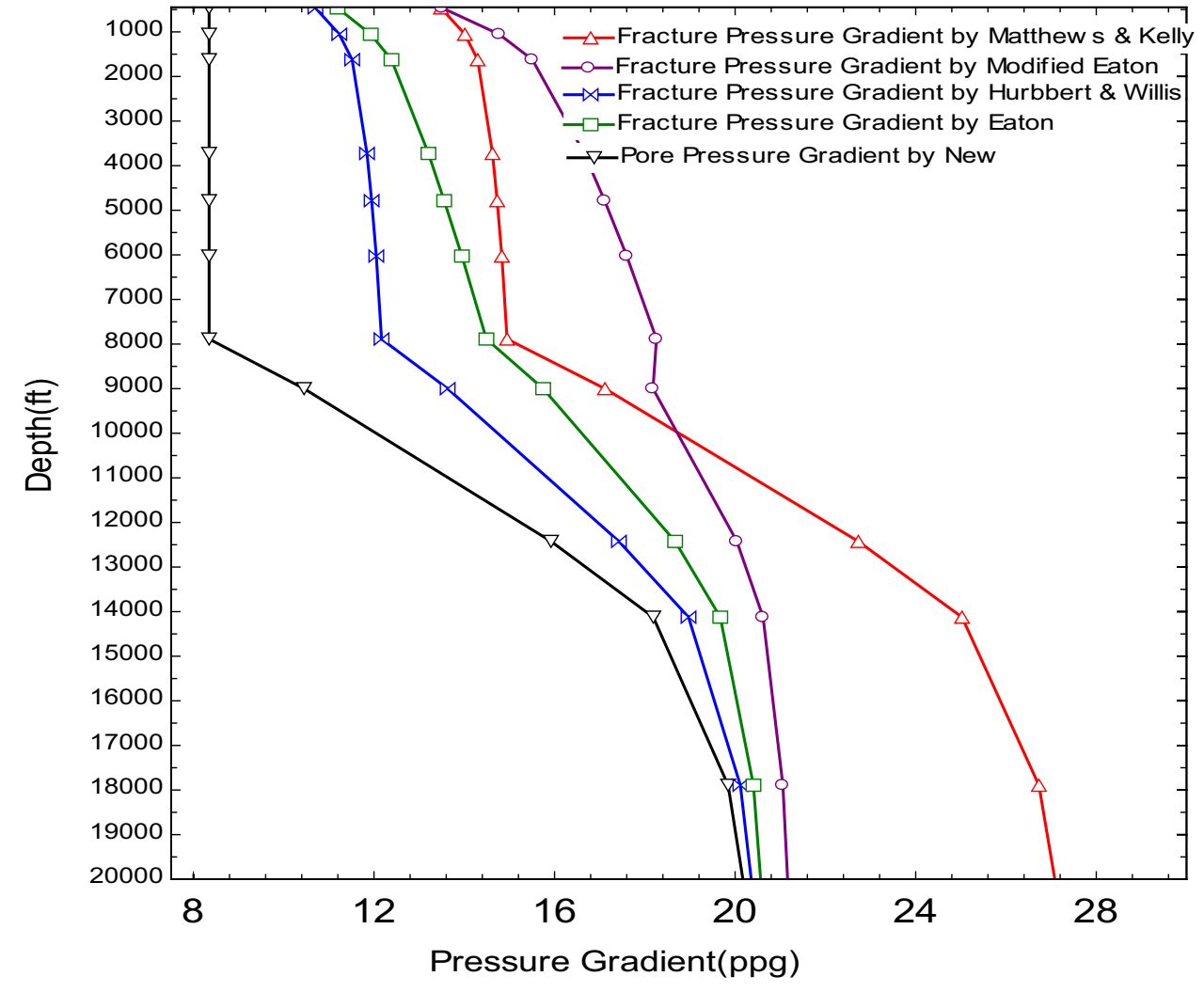


Table 10 Fracture pressure on the Tulamura anticline using pore pressure by the proposed new equation

\begin{tabular}{|c|c|c|c|c|c|c|}
\hline DEPTH $(\mathrm{Ft})$ & $\begin{array}{l}\text { Overburden } \\
\text { pressure } \\
\text { (Psi) }\end{array}$ & $\begin{array}{l}\text { Pore pressure by } \\
\text { modified Eaton } \\
\text { (Psi) }\end{array}$ & $\begin{array}{l}\text { Fracture pressure by } \\
\text { Hubbert and Willis } \\
\text { (Psi) }\end{array}$ & $\begin{array}{l}\text { Fracture pressure by } \\
\text { Matthews and Kelly } \\
\text { (Psi) }\end{array}$ & $\begin{array}{l}\text { Fracture pressure } \\
\text { by Eaton's equation } \\
\text { (Psi) }\end{array}$ & $\begin{array}{l}\text { Fracture pressure by } \\
\text { modified Eaton (Psi) }\end{array}$ \\
\hline 8.01 & 46.87 & - & - & - & - & - \\
\hline 464.40 & 372.10 & 258.39 & 258.87 & 325.57 & 270.20 & 326.25 \\
\hline 1054.33 & 931.86 & 615.65 & 616.73 & 768.16 & 653.79 & 809.78 \\
\hline 1623.04 & 1506.85 & 971.84 & 973.51 & 1206.62 & 1044.97 & 1308.97 \\
\hline 3727.60 & 3650.09 & 2295.12 & 2298.95 & 2834.33 & 2559.46 & 3228.27 \\
\hline 4782.87 & 4760.12 & 2970.43 & 2975.35 & 3662.29 & 3370.81 & 4254.27 \\
\hline 6024.61 & 6092.59 & 3773.83 & 3780.03 & 4645.31 & 4369.23 & 5513.95 \\
\hline 7886.94 & 8118.66 & 4987.97 & 4996.08 & 6128.84 & 5942.73 & 7488.40 \\
\hline 9000.92 & 9358.83 & 6379.31 & 7059.54 & 8009.15 & 7371.29 & 8509.44 \\
\hline $12,425.90$ & $13,199.24$ & $11,256.97$ & $11,408.40$ & $14,685.59$ & $12,062.00$ & $12,948.47$ \\
\hline $14,125.54$ & $15,078.66$ & $13,930.70$ & $13,671.22$ & $18,382.95$ & $14,449.89$ & $15,146.57$ \\
\hline $17,894.74$ & $19,227.43$ & $18,717.31$ & $18,007.40$ & $24,871.39$ & $18,987.30$ & $19,591.21$ \\
\hline $21,675.47$ & $23,421.52$ & $23,161.43$ & $22,158.95$ & $30,838.56$ & $23,316.63$ & $23,941.60$ \\
\hline $25,314.80$ & $27,454.46$ & $27,338.80$ & $26,106.58$ & $36,432.46$ & $27,414.25$ & $28,081.45$ \\
\hline $31,717.75$ & $34,569.03$ & $34,540.69$ & $32,967.17$ & $46,049.53$ & $34,561.37$ & $35,354.29$ \\
\hline
\end{tabular}

Fig. 19 Optimum mud weight on the top of the Tulamura anticline

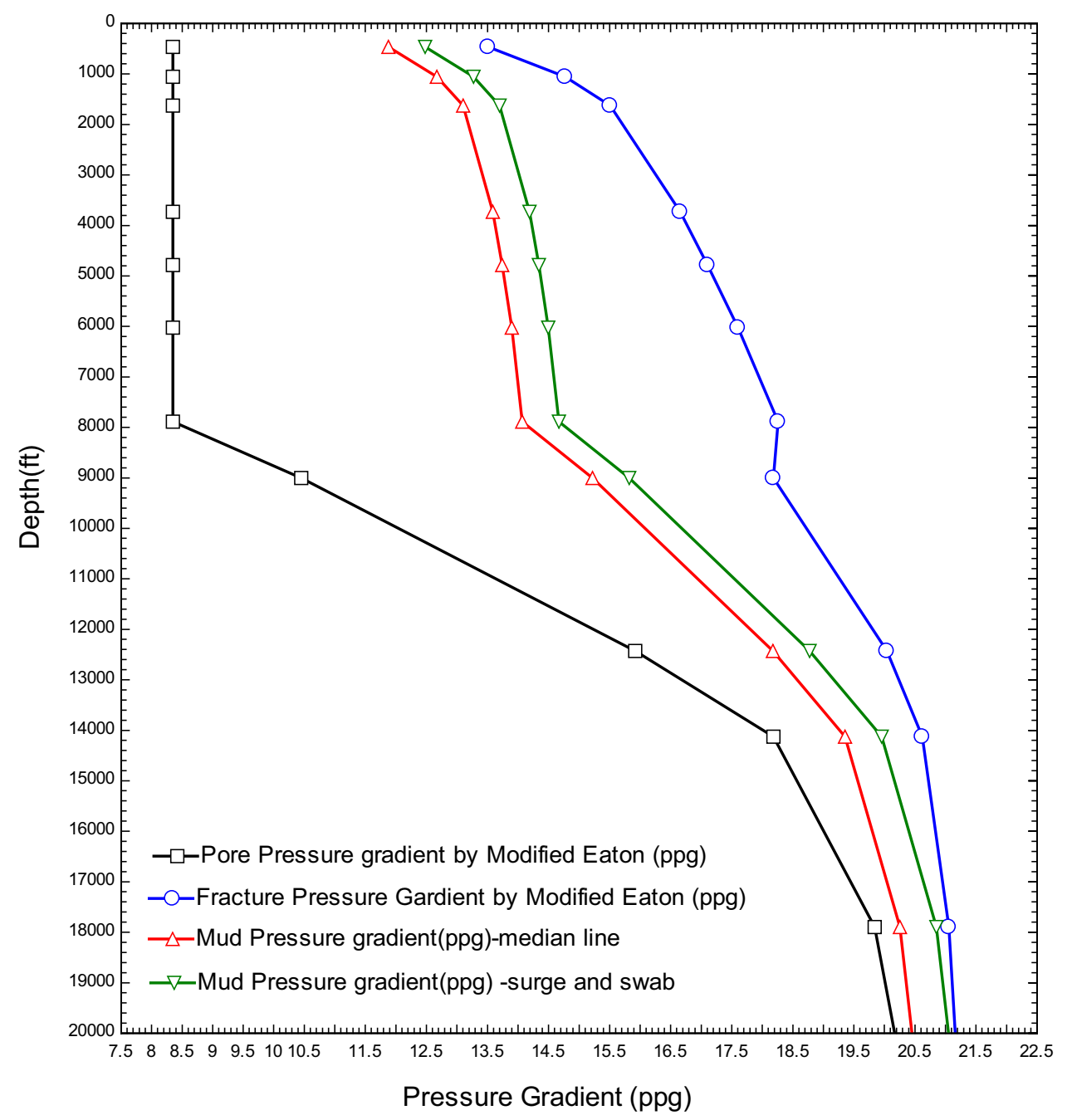

Pressure Gradient (ppg) 
Table 11 Optimum mud weight by median line principle on the top of The Tulamura anticline

\begin{tabular}{rllllc}
\hline Depth (Ft) & $\begin{array}{l}\text { Overburden pressure } \\
\text { gradient (ppg) }\end{array}$ & $\begin{array}{l}\text { Pore pressure gradient by } \\
\text { modified Eaton (ppg) }\end{array}$ & $\begin{array}{l}\text { Fracture pressure gradient } \\
\text { by modified Eaton (ppg) }\end{array}$ & $\begin{array}{l}\text { Mud pressure gradient } \\
\text { (ppg) median line }\end{array}$ & $\begin{array}{l}\text { Mud pressure gradient } \\
\text { (ppg) surge and swab }\end{array}$ \\
\hline 108.01 & 8.35 & - & - & - & - \\
464.40 & 15.41 & 8.35 & 13.5098 & $11.87,691$ & $12.47,691$ \\
1054.33 & 17.00 & 8.35 & $14.77,016$ & $12.67,115$ & $13.27,115$ \\
1623.04 & 17.85 & 8.35 & 15.50946 & 13.09975 & 13.69975 \\
3727.60 & 18.83 & 8.35 & 16.65472 & 13.58815 & 14.18815 \\
4782.87 & 19.14 & 8.35 & 17.10539 & 13.74234 & 14.34234 \\
6024.61 & 19.45 & 8.35 & 17.60072 & 13.89658 & 14.49658 \\
7886.94 & 19.80 & 8.35 & 18.25901 & 14.07058 & 14.67058 \\
9000.92 & 20.00 & 10.45 & 18.18071 & 15.22107 & 15.82107 \\
12425.90 & 20.43 & 15.92 & 20.03952 & 18.17318 & 18.77318 \\
14125.54 & 20.53 & 18.18 & 20.62082 & 19.35623 & 19.95623 \\
17894.74 & 20.66 & 19.84 & 21.0539 & 20.25181 & 20.85181 \\
21675.47 & 20.78 & 20.43 & 21.24131 & 20.60682 & 21.20682 \\
25314.80 & 20.86 & 20.72 & 21.33249 & 20.79029 & 21.39029 \\
31717.75 & 20.96 & 20.93 & 21.43563 & 20.94664 & 21.54664 \\
\hline
\end{tabular}

Table 12 Casing properties

\begin{tabular}{|c|c|c|c|c|c|c|c|}
\hline $\begin{array}{l}\text { Casing diam- } \\
\text { eter (inch) }\end{array}$ & $\begin{array}{l}\text { Nominal weight } \\
\left(\mathrm{lb}_{\mathrm{m}} / \mathrm{ft}\right)\end{array}$ & Grade & $\begin{array}{l}\text { Wall thickness } \\
\text { (inch) }\end{array}$ & $\begin{array}{l}\text { Pipe body yield } \\
\text { strength } 1000 \mathrm{lbf}\end{array}$ & $\begin{array}{l}\text { Joint strength } \\
1000 \mathrm{lbf}\end{array}$ & $\begin{array}{l}\text { Collapse resist- } \\
\text { ance psi }\end{array}$ & Blast resistance psi \\
\hline $20^{\prime \prime}$ & 94.00 & K-55 & 0.438 & 1480 & 955 & 520 & 2110 \\
\hline 13 3/8" & 92.50 & Q-125 & 0.672 & 3352 & 1690 & 5950 & 10,990 \\
\hline $95 / 8^{\prime \prime}$ & 70.30 & V-150 & 0.734 & 3075 & 2185 & 18,800 & 16,680 \\
\hline $7^{\prime \prime}$ & 38.00 & P-110 & 0.540 & 1205 & 1087 & 15,140 & 14,850 \\
\hline 7" & 42.70 & V-150 & 0.625 & 1875 & 1514 & 24,390 & 23,440 \\
\hline
\end{tabular}

Table 13 Calculated collapse pressure and burst pressure at casing shoe depth

\begin{tabular}{lllllc}
\hline Depth (ft) & $\begin{array}{l}\text { Open hole } \\
\text { diameter (inch) }\end{array}$ & $\begin{array}{l}\text { Casing diam- } \\
\text { eter (inch) }\end{array}$ & Type of casing & $\begin{array}{l}\text { Collapse pres- } \\
\text { sure (psi) }\end{array}$ & Burst pressure (psi) \\
\hline 100 & $26^{\prime \prime}$ & $20^{\prime \prime}$ & Conductor & - & $11,809.39$ \\
6050 & $171 / 2^{\prime \prime}$ & $133 / 8^{\prime \prime}$ & Surface & 4593.16 & 9223.05 \\
13,500 & $121 / 4^{\prime \prime}$ & $95 / 8^{\prime \prime}$ & Intermediate & $13,616.96$ & 6451.91 \\
18,500 & $91 / 2^{\prime \prime}$ & $7^{\prime \prime}$ & Production & $18,181.8$ & 4558.91 \\
\hline
\end{tabular}

Table 14 Kick tolerance parameter calculation

\begin{tabular}{lllllllll}
\hline Depth (ft) & Casing size (in) & $\begin{array}{l}\text { Fracture pressure } \\
\text { gradient at shoe } \\
\text { (ppg) }\end{array}$ & $\begin{array}{l}\text { Pore pressure } \\
\text { gradient at shoe } \\
\text { (ppg) }\end{array}$ & $\begin{array}{l}\text { Mud } \\
\text { weight } \\
\text { (ppg) }\end{array}$ & $\begin{array}{l}\text { Borehole } \\
\text { diameter } \\
\text { (in) }\end{array}$ & $\begin{array}{l}\text { Open hole } \\
\text { annulus capacity } \\
\text { (bbl/ft) }\end{array}$ & $\begin{array}{l}\text { Height of a } \\
\text { gas bubble } \\
\text { (ft) }\end{array}$ & $\begin{array}{l}\text { Influx volume at } \\
\text { casing shoe (bbl) }\end{array}$ \\
\hline 100 & $20^{\prime \prime}$ & 14 & 8.38 & 12 & $26^{\prime \prime}$ & 0.6140 & - & - \\
6050 & $133 / 8^{\prime \prime}$ & 18 & 8.38 & 14 & $171 / 2^{\prime \prime}$ & 0.2548 & 2947.30 & 750.97 \\
13,500 & $95 / 8^{\prime \prime}$ & 20.5 & 17 & 19.5 & $121 / 4^{\prime \prime}$ & 0.1031 & 2466.01 & 243.54 \\
18,500 & $7^{\prime \prime}$ & 21 & 20 & 20.5 & $91 / 2^{\prime \prime}$ & 0.0450 & 2386.48 & 107.463 \\
\hline
\end{tabular}


Fig. 20 Kick tolerance (bbl) versus depth $(\mathrm{m})$ on the top of Tulamura

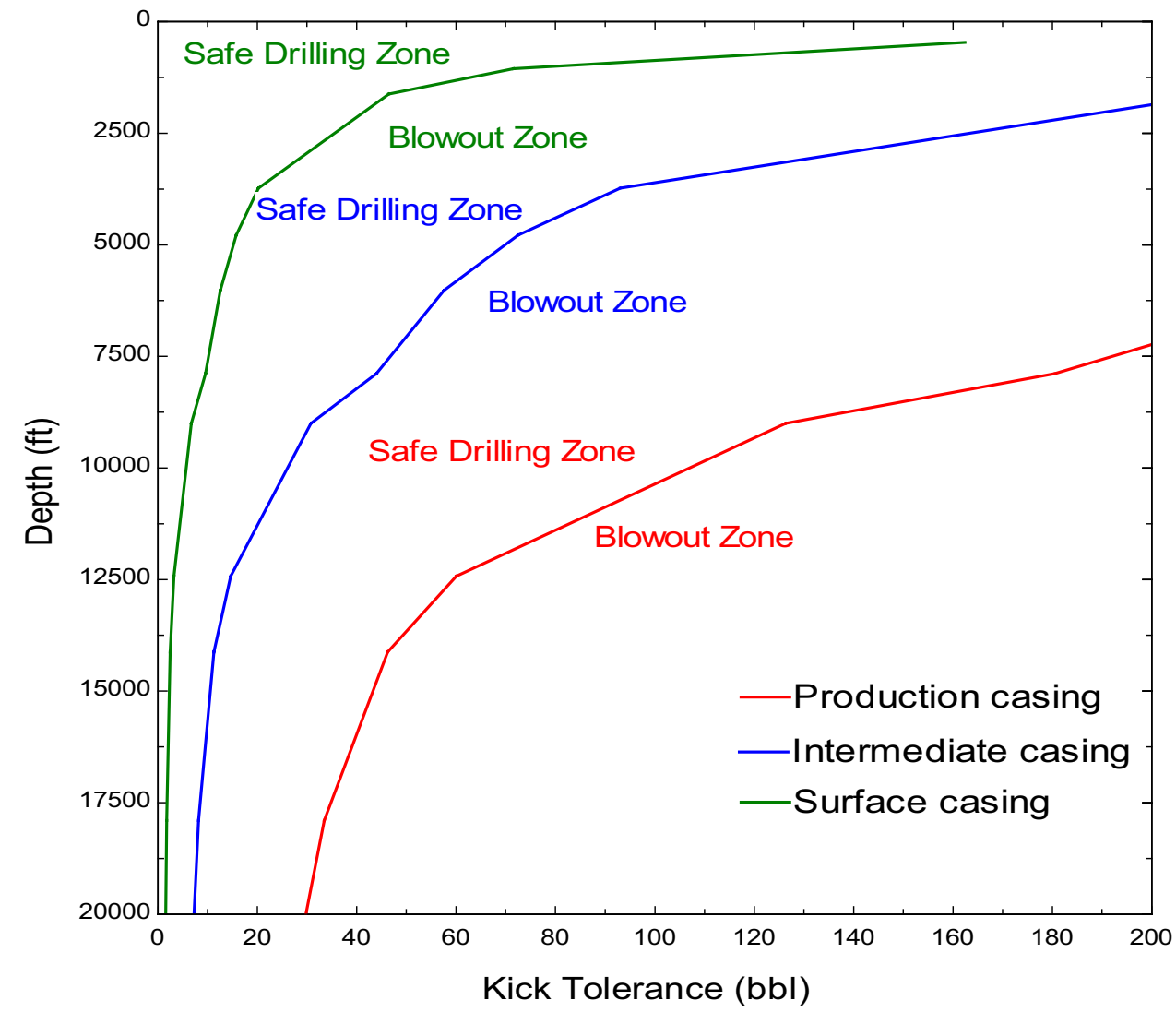

Table 15 Cement slurry volume calculation for the cementing

\begin{tabular}{llllll}
\hline Type of casing & $\begin{array}{l}\text { Open hole diam- } \\
\text { eter (inch) }\end{array}$ & $\begin{array}{l}\text { Casing diameter } \\
\text { (inch) }\end{array}$ & $\begin{array}{l}\text { Casing shoe } \\
\text { depth (ft) }\end{array}$ & $\begin{array}{l}\text { Annular capacity between open } \\
\text { hole and casing (bbl/ft) }\end{array}$ & $\begin{array}{l}\text { Cement slurry volume } \\
\text { required for cementing } \\
\text { (bbl) }\end{array}$ \\
\hline Conductor & $26^{\prime \prime}$ & $20^{\prime \prime}$ & 100 & 0.2681 & 26.81 \\
Surface & $171 / 2^{\prime \prime}$ & $133 / 8^{\prime \prime}$ & 6050 & 0.1237 & 748.52 \\
Intermediate & $121 / 4^{\prime \prime}$ & $95 / 8^{\prime \prime}$ & 13,500 & 0.0557 & 414.95 \\
Production & $91 / 2^{\prime \prime}$ & $77^{\prime \prime}$ & 18,500 & 0.0400 & 1279.64 \\
& & & & Total & $2470.00 \mathrm{bbl}$ \\
\hline
\end{tabular}

\section{Comparison between proposing well design based on the pore pressure by a new method and based on pore pressure by modified Eaton's method}

\section{Summary and conclusions}

It has been observed that pore pressure predicted by the new method is excellently matched with offset well data (RFT) along with excellently matched pore pressure predicted by the modified Eaton's method.
Comparatively, it has been observed that in the new method, normal velocity data from the compaction trend are not the necessary input; thus, the error caused by normal velocity has been eliminated where in the modified Eaton's method the normal velocity may cause the error.

The new method has been successfully applied to seismic data and turned out to be reliable to repeat formation test data; it provides a new way to predict pore pressure and contributes much to the next step exploration and exploitation. The proposed new method has the potential to perform better in pore pressure prediction than modified Eaton's method. 


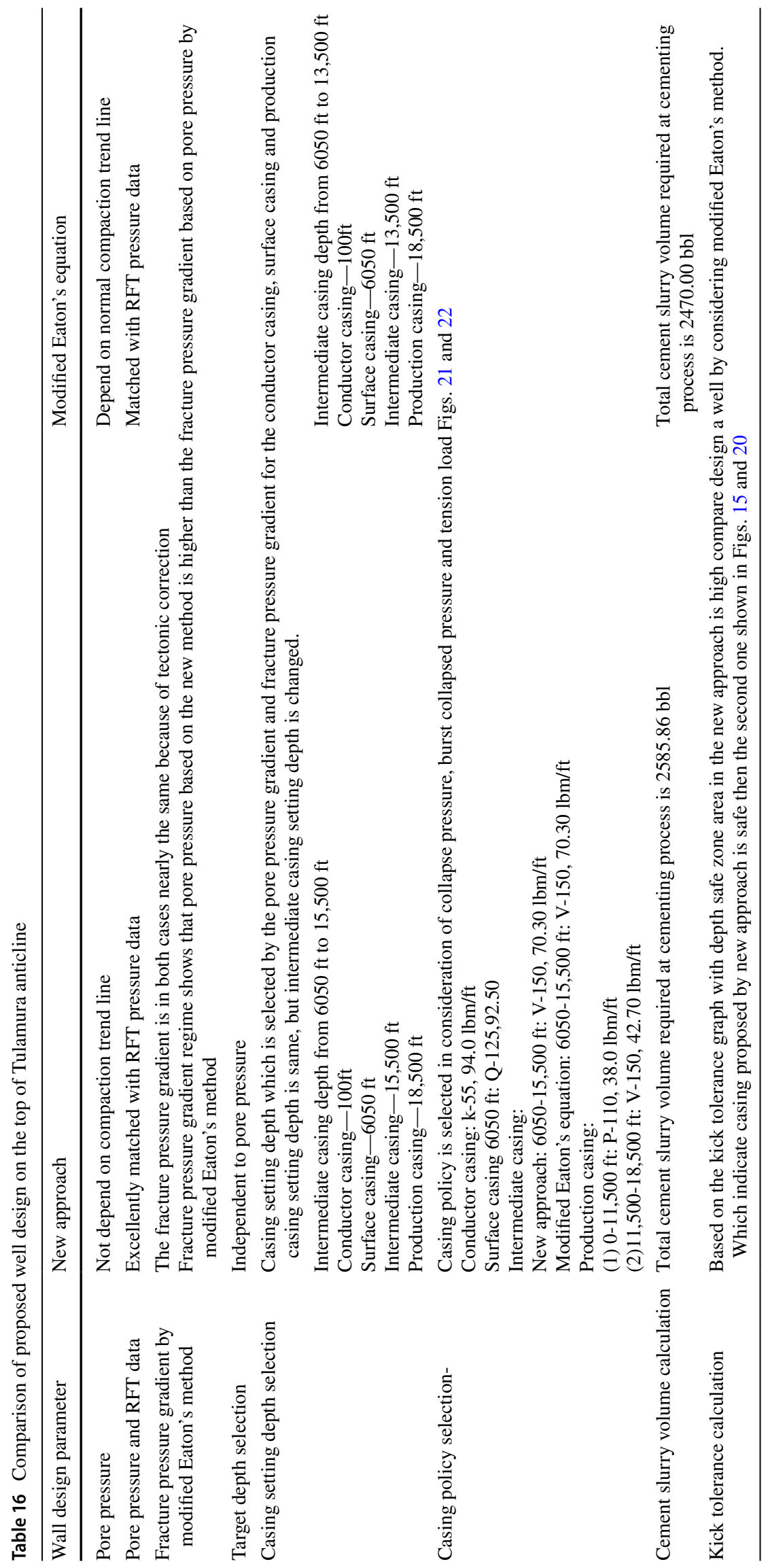


Fig. 21 Proposed well design by a new method

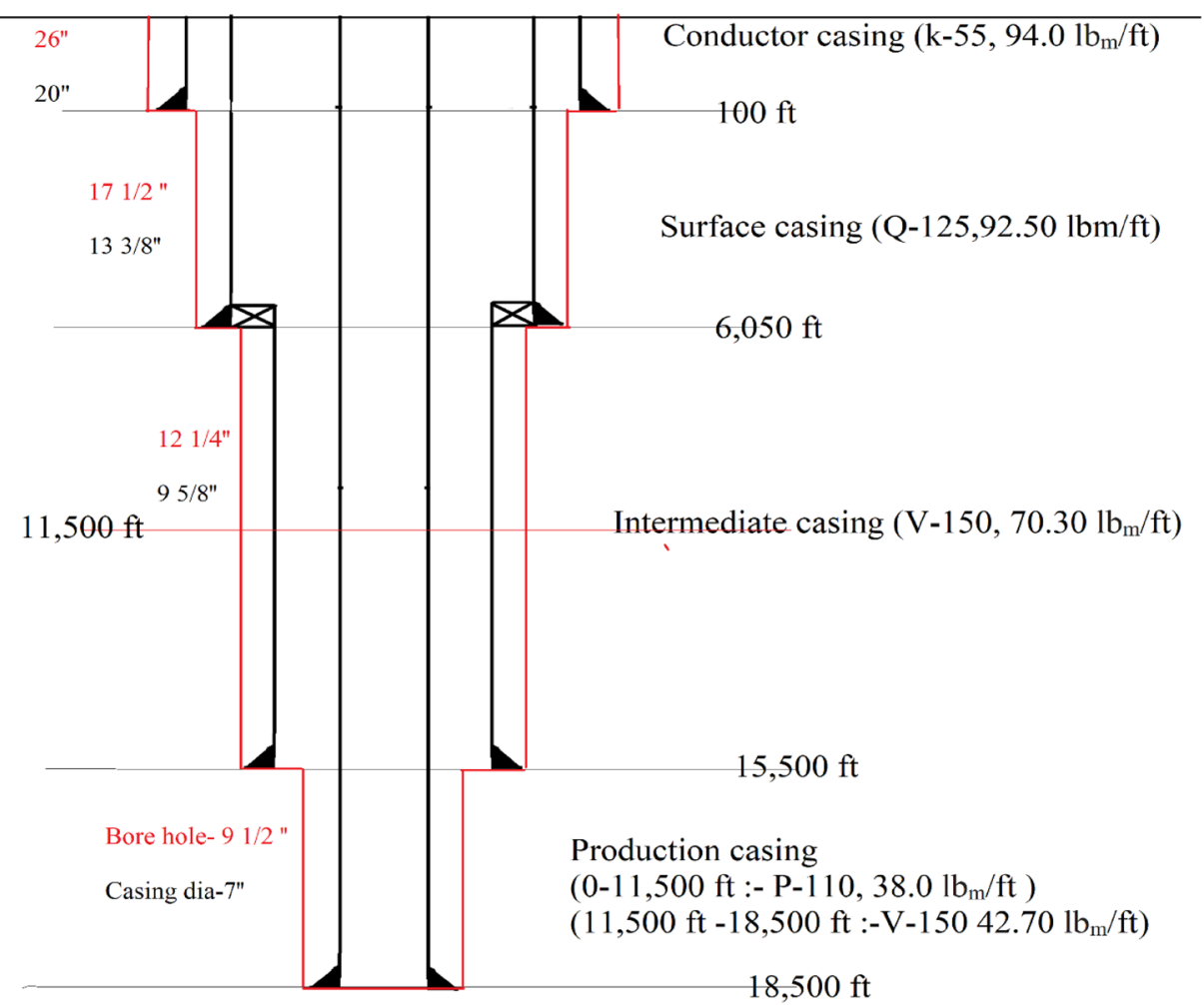

In this study, it has been observed that that pore pressure is drastically increased by the depth of $8000 \mathrm{ft}$, and abnormal formation pressure is between $8000 \mathrm{ft}$ and $20,000 \mathrm{ft}$. Tulamura is a very complex geological structure with normal faults that are frequent so that Poisson's ratio may vary with depth. Fracture pressure by Eaton and modified Eaton's method gives more readable value because of the variable Poisson ratio. Suitable mud weight by median line principle is calculated and improved via considering $0.3 \mathrm{ppg}$ trip margin, $0.3 \mathrm{ppg}$ surge pressure gradient and $0.2 \mathrm{ppg}$ safety factor for calculation of all casing pipes.

From pore pressure gradient, fracture pressure gradient and mud weight using graphical method, four types of casing setting depth are selected: conductor casing, surface
Fig. 22 Proposed well by modified Eaton's method

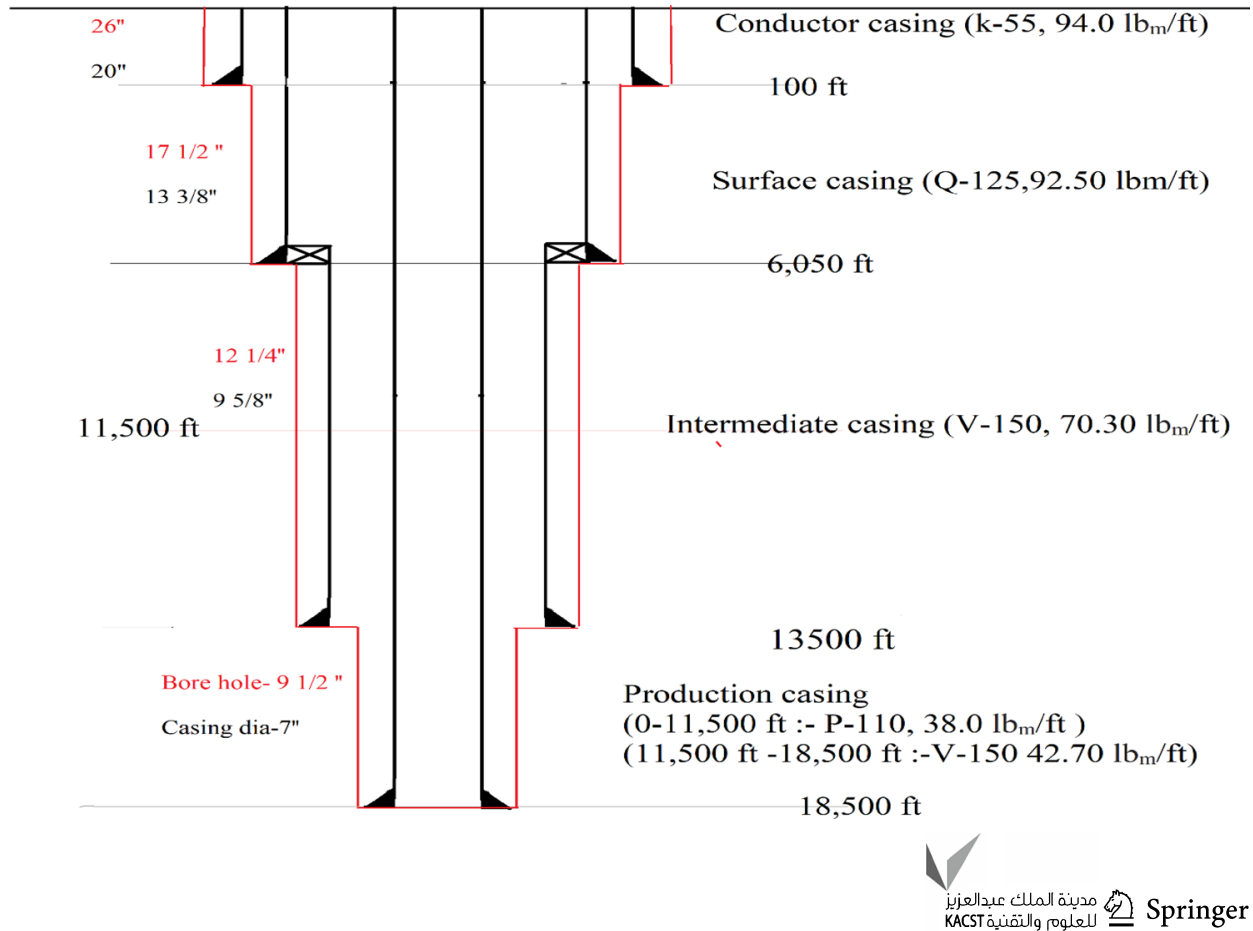


casing, intermediate casing and production casing. After casing depth determination, casing dimension, nominal weight and grade are selected from calculated burst pressure, collapse pressure and tension load. For each casing, kick volume in bbl is calculated and is given by kick tolerance for safe drilling.

Finally, a comparison between proposed well design by a new approach and modified Eaton's method is given in Table 16, and the final proposed well plan is given in Figs. 21 and 22.

This study gives all the detailed flows of designing an exploratory well in the overpressure zone. The seismic survey uses only raw data for virgin area to exploration and exploitation of hydrocarbon. To drill a well in overpressure zone, the idea of pore pressure, fracture pressure, drilling mud weight required casing policy; kick tolerance graph plays an important role for driller. This study gives all guidelines for driller to eliminate the loss throw blowout and uncertainties. This study is only based on seismic velocity data; therefore, to get more reliable pore pressure prediction and design of safe well different types of data such as density data and well log data are suggested.

Open Access This article is distributed under the terms of the Creative Commons Attribution 4.0 International License (http://creativeco mmons.org/licenses/by/4.0/), which permits unrestricted use, distribution, and reproduction in any medium, provided you give appropriate credit to the original author(s) and the source, provide a link to the Creative Commons license, and indicate if changes were made.

\section{References}

Adams JN, Charrier T (1985) Drilling engineering: a complete well planning approach. PennWell Corporation

Akram SM et al. (2004) Geodata integration leads to reserve accretion in Baramura gas field of Tripura, Assam-Arakan Fold Belta case study. Hyderabad. In: 5th Conference and exposition on petroleum geophysics

Alam M (1989) Geology and depositional history of Cenozoic sediments of the Bengal Basin of Bangladesh. Palaeogeogr Palaeoclimatol Palaeoecol 69:125-139

Bhagwan S, Singh O, Awadhesh R, Talukdar B (1998) Occurrence of overpressures and its implications for hydrocarbon exploration in North East India. New Delhi, India, society of petroleum engineers.inc, pp 653-666

Brahma J, Sircar A (2018) Design of safe well on the top of Atharamura anticline, Tripura, India, on the basis of predicted pore pressure from seismic velocity data. J Pet Explor Prod Technol 8(4):1209-1224

Brahma J, Sircar A, Karmakar GP (2013a) Hydrocarbon prospectivity in central part of Tripura, India, using an integrated approach. J Geogr Geol 5(3):116-134

Brahma J, Sircar A, Karmakar GP (2013b) Pre-drill pore pressure prediction using seismic velocities data on flank and synclinal part of Atharamura anticline in the Eastern Tripura, India. J Pet Explor Prod Technol 3(2):93-103

Chakravorty D, Gupta SSRBA (2011) A re-look into exploration strategy of Lower Bhuban play in Eastern Tripura, India- a case study. New Delhi, India. In: The 2nd South Asian geoscience conference and exhibition

das Jena AK, Saha NCGC, Samanta A (2011) Exploration in synclinal areas of Tripura fold belt, India: a re-found opportunity. AAPG Annual Convention and Exhibition, Houston

DEHRADUN ONGC (2002) Drilling operation manual. Institute of Drilling Technology ONGC, Dehradun

Dejam M (2019a) Tracer dispersion in a hydraulic fracture with porous walls. Chem Eng Res Des 150:169-178

Dejam M (2019b) Advective-diffusive-reactive solute transport due to non-Newtonian fluid flows in a fracture surrounded by a tight porous medium. Int J Heat Mass Transf 128:1307-1321

Dejam M, Hassanzadeh H (2018) The role of natural fractures of finite double-porosity aquifers on diffusive leakage of brine during geological storage of $\mathrm{CO}_{2}$. Int J Greenhouse Gas Control 78:177-197

Dejam M, Hassanzadeh H, Chen Z (2018) Shear dispersion in a roughwalled fracture. SPE J 23:5

Dix CH (1995) Seismic velocities from surface measurements. Geophysics 20:69-86

Eaton BA (1969) Fracture gradient prediction and its application in oilfield operations. J Petrol Technol 21(10):1353-1360

Eaton BA (1975) The equation for geopressure prediction from well logs. In: Fall Meeting of the Society of Petroleum Engineers of AIME

Elmahdy M, Farag AE, Tarabees E, Bakr A (2018) Pore pressure prediction in unconventional carbonate reservoir. In: SPE Kingdom of Saudi Arabia annual technical symposium and exhibition. Society of Petroleum Engineers

Gabolde G, Nguyen JP (2006) Drilling data handbook 7th edn. Technip

Hottmann C, Johnson R (2007) Estimation of formation pressures from log-derived shale properties. Journal of Petroleum Technology 17:717-722

Hubbert MK, Rubey WW (1959) Role of fluid pressure in mechanics of overthrust faulting: i. Mechanics of fluid-filled porous solids and its application to overthrust faulting Gsa Bulletin. Geol Soc Am Bull 1959 6:115-166

Karl TRB (1996) Soil mechanics in engineering practice. Soil Sci 592:63

Matthews WR (1967) How to predict formation pressure and fracture gradient from electric and sonic logs. Oil and Gas

Momin WW, Choudhury A (1999) Evaluation of Tripura subbasin with special reference to the hydrocarbon province of Bangladesh gas fields. In: Proceedingof the 3rd international petroleum conference and exhibition. Petrotech, New Delhi, India, pp 63-68

Radwan AE, Abudeif A, Attia MM, Mohammed MA (2019) Pore and fracture pressure modeling using direct and indirect methods in Badri Field, Gulf of Suez, Egypt. J Afr Earth Sci. https://doi. org/10.1016/j.jafrearsci.2019.04.015

Sayers CM, Johnson GM, Denyer G (2000) Pore pressure prediction from seismic tomography. In: Offshore technology conference

Yan F, Han D-h, Ren K (2013) A new model for pore pressure prediction. s.1., SEG Las Vegas 2012. In: Annual Meeting

Zhang L, Kou Z, Wang H, Zhao Y, Dejam M, Guo J, Du J (2018) Performance analysis for a model of a multi-wing hydraulically fractured vertical well in a coalbed methane gas reservoir. J Petrol Sci Eng 166:104-120 


\section{Affiliations}

\section{Mohatsim Mahetaji ${ }^{1}$. Jwngsar Brahma ${ }^{1}$. Anirbid Sircar ${ }^{1}$}

Mohatsim Mahetaji

mohatsimmehtaji@gmail.com

Anirbid Sircar

Anirbid.Sircar@spt.pdpu.ac.in
Pandit Deendayal Petroleum University, Knowledge Corridor, Raisan Village, Gandhinagar 382007, Gujarat, India 